\title{
REgULATING DISRUPTIVE INNOVATION
}

\author{
Nathan Corteq ${ }^{\dagger}$
}

\begin{abstract}
Disruption theory tells us that certain innovations can undermine existing products, firms, or even entire industries. Classic examples include the Kodak camera, the Bell telephone, and the Ford Model T. Modern examples abound. The market entrant's innovation ultimately displaces industry incumbents. Regulators, too, are challenged by such disruptive innovations. The new product, technology, or business practice may fall within an agency's jurisdiction but not square well with the agency's existing regulatory framework. Call this "regulatory disruption."

Most scholars intuit that regulators should be cautious rather than firm in such situations. Tim Wu, in Agency Threats, argues that agencies confronting disruptive innovations should avoid traditional rulemaking and adjudication, and instead rely on "threats" packaged in guidance documents, warning letters, and the like. Threats, he argues, are less burdensome, more flexible, and avoid regulation that is miscalibrated or premature. However, this Article argues that a flexible initial posture based primarily on "threats" can calcify, creating weak defaults that lead to suboptimal regulation in the long term. Regulatory inertia can be hard to break without an external shock, usually a tragedy or some other massive failure that reignites interest in regulation. As a case study, this Article shows how the FDA's approach to a disruptive technology (computerized medical devices) twenty-five years ago fits the threat framework strikingly well, and how it failed. The FDA's threats became stale and counterproductive — during a profound computer revolution, no less. This Article counterposes the FDA's approach to software with the FCC's approach to the Internet, which initially relied on threats, but later codified them via binding regulations and enforcement shortly thereafter.

This Article argues that agencies need not be so tentative with innovations. If agencies are concerned about regulating prematurely or in error, then they can experiment with timing rules, alternative enforcement mechanisms, and other variations on traditional interventions. If agencies do choose to proceed by making threats, then they should use them as a short-term precursor to more decisive, legally binding action, as the FCC did, and avoid relying on them as a long-term crutch, as the FDA did.
\end{abstract}

(C) 2014 Nathan Cortez.

† Nathan Cortez, Associate Professor and Associate Dean for Research, Southern Methodist University ("SMU”), Dedman School of Law. J.D., Stanford University, B.A., University of Pennsylvania. Many thanks to Nicholas Bagley, Jeffrey Bellin, Glenn Cohen, Lars Noah, Jordan Paradise, Frank Pasquale, Nicolas Terry, and David Zaring for commenting on earlier drafts. I also received valuable comments and questions from participants at the American Society of Law, Medicine, and Ethics ("ASLME") annual meeting, the SMU Law School Faculty Forum, and at the Harvard Law School's Petrie-Flom Center conference on "The Food and Drug Administration in the 21st Century" (May 4, 2013). I thank Courtney Eudy, Banee Pachuca, and Robert Thetford for their excellent research. An earlier version of this Article was selected for the "New Voices in Administrative Law" program at the 2013 AALS Annual Meeting (Jan. 5, 2013). Finally, this research was supported by generous funding from the A.J. and Ann Van Wynen Thomas Memorial Endowed Research Award. 


\section{TABLE OF CONTENTS}

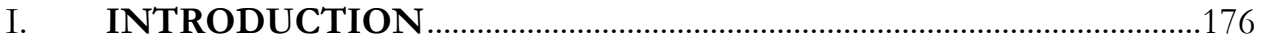

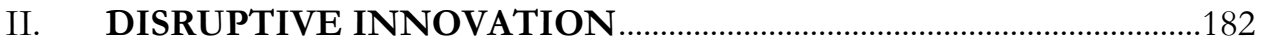

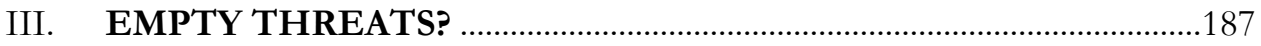

A. AGENCY THREATS.............................................................................187

B. THE FDA AND THE QUARTER-CENTURY-LONG THREAT …….........191

C. THE FCC AND THE SIX-YEAR-LONG THREAT......................................196

IV. THE REGULATORY TOOLKIT FOR DISRUPTIVE

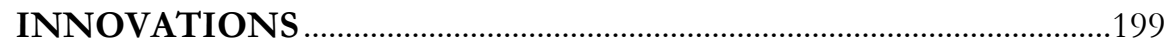

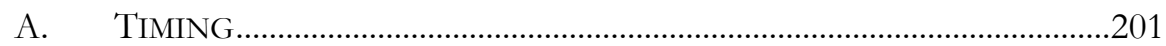

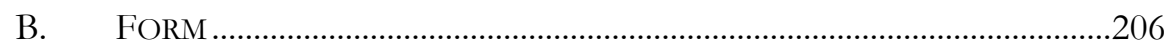

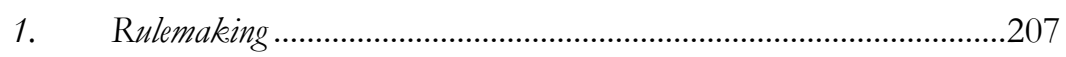

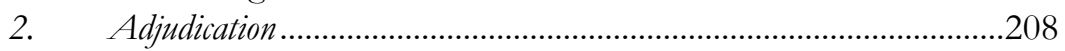

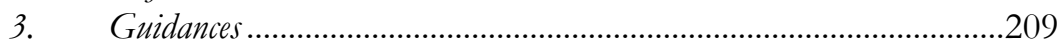

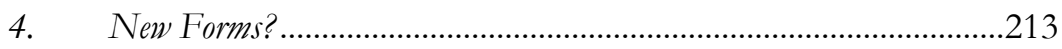

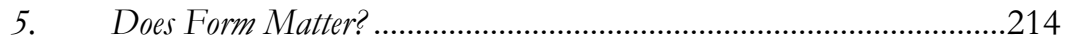

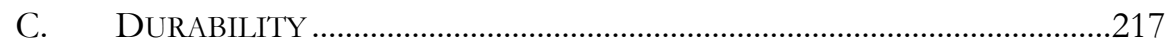

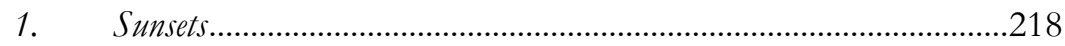

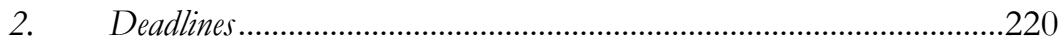

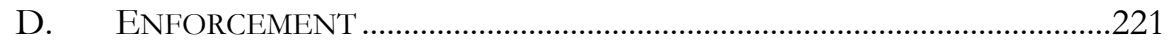

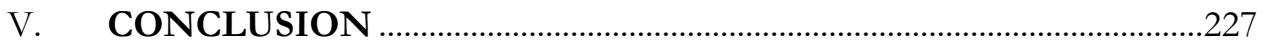

\section{INTRODUCTION}

A persistent challenge for regulators is confronting new technologies or business practices that do not square well with existing regulatory frameworks. These innovations can depart in important ways from older incumbents. For example, the innovation might present unanticipated benefits and risks. It might disturb carefully crafted equilibria between regulators, industry, and consumers. The innovation might puncture prevailing regulatory orthodoxies, forcing regulators to reorient their postures or even rethink their underlying statutory authority. The quintessential example is the Internet, which rumpled not just one, but several regulatory frameworks, including those of the Federal Communications Commission ("FCC"), the Federal Trade Commission ("FTC"), and the Food and Drug Administration ("FDA").

1. For the FCC's experience adapting its longstanding regulatory framework to Internet providers, see infra Section III.C. For the FTC's experience adapting its longstanding frameworks for privacy, marketing fraud, and antitrust violations to online 
Periodically, our economy generates these "disruptive innovations."2 Joseph Bower and Clayton Christensen introduced the idea to describe new technologies that undermine and eventually displace established products, firms, or even entire industries. Iconic examples include automobiles, personal computing, and cellular phones. But the idea's explanatory power extends to many other products and industries. As a result, disruption theory has inspired prolific writing in the business academy and now creeps into other disciplines. ${ }^{3}$

Here, this Article uses the idea to refer to innovations that disrupt existing regulatory schemes, not necessarily industry incumbents (though they may do that too). Call this "regulatory disruption." Legal scholars have examined distuptive innovation in various disciplines, such as civil

activities, see, for example, Babette E.L. Boliek, FCC Regulation Versus Antitrust: How Net Neutrality Is Defining the Boundaries, 52 B.C. L. REV. 1627, 1652-82 (2011) (comparing the suitability of FCC regulation versus FTC antitrust jurisdiction in crafting net neutrality policies); Steven Hetcher, The FTC as Internet Privacy Norm Entrepreneur, 53 VAND. L. REV. 2041, 2053 (2000) (using public choice theory to explain the FTC's approach to online privacy); Jay P. Kesan \& Andres A. Gallo, Optimizing Regulation of Electronic Commerce, 72 U. CIN. L. REV. 1497, 1605-22 (2004) (considering in detail the FTC's regulation of online consumer fraud from a microeconomic and game-theoretical perspective). For an amusing juxtaposition that highlights the friction between new technologies and older regulatory frameworks, see Rep. George W. Gekas \& James W. Harper, Annual Regulation of Business Focus: Regulation of Electronic Commerce, 51 ADMIN. L. REV. 769, 772, 777 (1999) (juxtaposing the heading “The Internet: Everything's New!" with the heading “Government: Everything's Old!"). For the FDA's early experience adapting its longstanding framework for regulating pharmaceutical labeling and advertising to new online promotional practices, see Peter S. Reichertz, Legal Issues Concerning the Promotion of Pharmaceutical Products on the Internet to Consumers, 51 FOOD \& DRUG L.J. 355, 357-61 (1996); Marc J. Scheineson, Legal Overview of Likely FD A Regulation of Internet Promotion, 51 FOOD \& DRUG L.J. 697 (1996).

2. See Joseph L. Bower \& Clayton M. Christensen, Disruptive Technologies: Catching the Wave, Harv. Bus. REV., Jan.-Feb. 1995, at 43, 45 (1995). Bower and Christensen did not discuss the term "disruptive innovation" in their 1995 article, but Christensen's follow-up book, Clayton M. Christensen, The Innovator's Dilemma: When New TeChNologies CAuse Great Firms to FAIL (1997), helped introduce and popularize the term.

3. For example, Christensen and colleagues have applied disruption theory to health care. See generally CLAYTON M. CHRistensen ET AL., The INNOVATOR's PRESCRIPTION: A DisRuptive SOLUTION FOR HEALTH CARE (2009). An early application of disruption theory to health care in the legal literature is Lesley H. Curtis \& Kevin A. Schulman, Overregulation of Health Care: Musings on Disruptive Innovation Theory, 68 L. \& CONTEMP. PROBS. 195 (2006). For a thoughtful analysis of why health information technologies have yet to disrupt the U.S. health care system, per Christensen's criteria, see Nicolas P. Terry, Information Technology's Failure to Disrupt Healthcare, 13 NEV. L.J. 722 (2013). For a skeptical review of The Innovator's Prescription, see J.D. Klienke, Perfection in PowerPoint, 28 HeALTH AfF. 1223 (2009) ("Although the book excavates several fascinating nuggets about wrenching changes in other industries, it attempts to force each into Christensen's franchise-in-progress, 'disruption theory." "). 
procedure, ${ }^{4}$ environmental law, ${ }^{5}$ and intellectual property. ${ }^{6}$ Health law scholarship predominates the legal literature on disruptive innovation, ${ }^{7}$ perhaps because our dysfunctional health care system begs for transformation. ${ }^{8}$ And, to be sure, there is no shortage of legal scholarship examining technological innovation more generally. ${ }^{9}$ But no one has yet applied disruption theory to the field in which it should be most usefuladministrative law. Administrative law scholarship contains a rich, sprawling discourse on how agencies should regulate new markets. ${ }^{10}$ These questions, incidentally, can be particularly vexing with categorically novel technologies and business practices. Contemporary debates in administrative law thus map well onto disruption theory, and for that reason it is worth merging the two here.

The one scholar that comes closest to merging disruption theory and administrative law theory is Tim Wu, in his recent essay Agency Threats. ${ }^{11} \mathrm{Wu}$

4. See, e.g., Cassandra Burke Robertson, The Facebook Disruption: How Social Media May Transform Civil Litigation and Facilitate Access to Justice, 65 ARK. L. REV. 75 (2012).

5. See, e.g., Joel B. Eisen, Can Urban Solar Become a "Disruptive" Technology?: The Case for Solar Utilities, 24 Notre Dame J.L. ETHics \& PuB. Pol'y 53 (2010).

6. See, e.g., Fred von Lohmann, Fair Use as Innovation Policy, 23 Berkeley TECH. L.J. 829 (2008).

7. Indeed, of the forty-eight articles in the Westlaw database "Journals and Law Reviews" ("JLR") that cite one or more of Clayton Christensen's publications on "disruptive innovation," roughly half of them are in the health law field (search conducted on Oct. 8, 2013).

8. Terry, supra note 3.

9. The vast majority of this scholarship focuses on intellectual property, for obvious reasons. But some does not. See, e.g., Ronald J. Gilson, Locating Innovation: The Endogeneity of Technology, Organizational Structure, and Financial Contracting, 110 COLUM. L. REV. 885 (2010).

10. The scholarship is too numerous to cite, but see, for example, Peter Huber, The Old-New Division in Risk Regulation, 69 VA. L. REV. 1025 (1983) (considering flaws in how Congress and federal regulators consider older, well-known risks versus newer, unkown ones); Gregory N. Mandel, History Lessons for a General Theory of Law and Technology, 8 MINN. J.L. SCI. \& TECH. 551 (2007) (deriving various lessons for policymakers after considering past responses to new technologies); Thomas O. McGarity \& Karl O. Bayer, Federal Regulation of Emerging Genetic Technologies, 36 VAND. L. REV. 461 (1983) (considering whether then-existing regulatory frameworks were adequate to regulate new genetic engineering technologies); Monroe E. Price, The Newness of New Technology, 22 CARDOZO L. REV. 1885 (2001) (examining how legal institutions address "the threat of the new," focusing mostly on information technologies).

11. Tim Wu, Agency Threats, 60 Duke L.J. 1841 (2011). Daniel Gervais also tackles the question of regulating what he calls "inchoate technologies," distinguishing these from more "stable" technologies. Daniel Gervais, The Regulation of Inchoate Technologies, 47 Hous. L. REV. 665, 671 (2010). Like Wu, his treatment is somewhat Internet-centric. Gervais argues for a general skepticism towards regulating inchoate technologies, and is less concerned with the timing and form of intervention. As such, Gervais seems primarily concerned with whether to regulate inchoate technologies, not how. Id. at 669. After these, the next closest to discussing 
does not invoke disruption theory per se, but does address how regulators should confront novel technologies, business models, and practices. ${ }^{12}$ In doing so, $\mathrm{Wu}$ engages a broader scholarly debate on the proper form of agency policymaking. ${ }^{13}$ He argues that agencies should forgo traditional policymaking tools like rulemaking and adjudication in favor of informal "threats" - packaged in guidance documents, warning letters, and the likewhen confronting industries that face conditions of rapid change and high uncertainty. ${ }^{14}$ An informal, elastic "threat regime" is preferable, he argues, when agencies face dynamic rather than static industries characterized by disruptive innovation, unexpected market entries, new business models, and other exogenous shocks. ${ }^{15}$ More traditional regulatory interventions like rulemaking and adjudication, the argument goes, risk being badly miscalibrated, or premature, or both. ${ }^{16}$

This Article tests the argument for agency threats and offers some important limitations. It argues that a regulatory threat works best as a temporary stopgap that presages more traditional regulatory intervention, not as a long-term strategy. Otherwise, the threat risks becoming stale or even counterproductive. Resource-strapped agencies that employ threats (most do) should guard carefully against relying on them as a long-term crutch. At some point, regulators must regulate.

In short, this Article demonstrates that agencies need not be so timid when confronting new technologies_-even disruptive ones. If agencies are concerned about imposing regulation that is miscalibrated or premature, then they can reduce the cost of errors by using timing rules, alternative enforcement mechanisms, and other variations that might "soften" traditional regulation without undermining it long-term. In essence, regulators can experiment with binding approaches that can be more finely calibrated to the novel technology or business practice. The public interest demands that agencies maintain their fortitude in the face of regulatory disruption. And, somewhat counterintuitively, new technologies can benefit

disruptive technologies and regulatory responses is Donald Labriola, Dissonant Paradigms and Unintended Consequences: Can (and Should) the Law Save Us from Technology?, 16 RICH. J.L. \& TECH. 1 (2009), although the article focuses on behavioral and social psychology rather than regulatory theory.

12. Wu uses the phrase "disruptive innovation" just once in Agency Threats, supra note 11, at 1848, and does not cite Christensen's work. However, he has cited it in previous writing. E.g., Tim Wu, The Master Switch: The Rise and Fall of Information EMPIRES 20 (2010).

13. See also infra Section IV.B.

14. Wu, supra note 11, at 1842.

15. Id. at 1848-49.

16. Id. at 1849 . 
from decisive, well-timed regulation. Some early regulatory interventions might even become, in Daniel Carpenter's words, "market-constituting," by enabling a robust market that otherwise might not exist, especially for credence goods that are difficult for consumers to evaluate. ${ }^{17}$

To make these points, this Article evaluates how a traditional regulatory agency, the FDA, has struggled to confront a technology that constantly evolves and reinvents itself-software. The FDA, responsible for regulating most new medical products, has spent the last century navigating waves of innovation in the food, drug, and medical device industries. ${ }^{18}$ Indeed, one of the agency's major charges is to act as a gatekeeper for new medical products. ${ }^{19}$

But computerized medical devices have confounded the agency over the last twenty-five years, pushing the FDA far beyond its regulatory comfort zone. The FDA first confronted computerized medical devices in the mid1980s, particularly after a series of patient deaths traced to the first radiation machines controlled by software. ${ }^{20}$ Following these deaths, the FDA published a 1987 draft guidance that explained what types of software the agency would and would not regulate, including the requirements that might apply. ${ }^{21}$ But the FDA relied on the draft guidance for the next eighteen years, withdrawing the policy unceremoniously in $2005,^{22}$ leaving nothing in its

17. Daniel Carpenter, Confidence Games: How Does Regulation Constitute Markets?, in Government And Markets: Toward a NeW Theory of Regulation 164, 170 (Edward J. Balleisen \& David A. Moss eds., 2010). As Carpenter explains:

[D]rugs are types of credence goods, whose quality consumers can assess neither through inspection (as for "inspection goods" like a tomato) nor experience (as for experience goods like a job). Such goods, social scientists have demonstrated both theoretically and empirically, create "lemons problems." Because of informational shortcomings, consumers will continually purchase or consume inferior products when superior alternatives are available....

Id. at 174 .

18. See Food \& Drug LAw Inst., FDA: A Century of Consumer Protection (Wayne L. Pines ed., 2006) (discussing various historical accounts of the FDA's response to developments in the food, drug, device, and biologics industries).

19. See generally DANiEl Carpenter, Reputation AND Power: Organizational Image AND PHARMACEUtical Regulation AT THE FDA (2010) (detailing an account of the FDA's gatekeeping role in pharmaceutical regulation).

20. For a fuller account of this incident, see infra Section III.B.

21. Draft Policy Guidance for Regulation of Computer Products, 52 Fed. Reg. 36,104 (Sept. 25, 1987) [hereinafter 1987 Notice of Draft Policy]; FDA Draft Policy for the Regulation of Computer Products (proposed Nov. 13, 1989) [hereinafter 1989 Draft Software Policy] (on file with author).

22. Annual Comprehensive List of Guidance Documents at the Food and Drug Administration, 70 Fed. Reg. 824,890 (Jan. 5, 2005). 
place. The FDA never promulgated comprehensive software regulations and never even finalized the draft policy. All of this happened during a profound computer revolution no less, when software became increasingly ubiquitous and critical to patient safety. Today, the FDA repeats this pattern, releasing guidance after guidance to address software technologies in medicine. ${ }^{23}$

The FDA's approach to software over the last quarter century fits the agency threat framework strikingly well. The software industry has always been dynamic, not static. Many observers believe that recent software innovations will disrupt prevailing health industry norms and practices. ${ }^{24}$ The FDA faces conditions of high uncertainty, to risk understatement. And the conventional wisdom has been that decisive software regulation by the agency would be premature. ${ }^{25}$ So the FDA has relied on guidance documents to explain its expectations. It has not made rules. It has made threats.

But looking back, the threats embodied in the FDA's 1987 draft guidance were largely empty. The FDA's tentative, short-term approach to an emerging technology calcified into a long-term default, ultimately leading to suboptimal regulation for an entire industry. What started as a modest, flexible response by the FDA, consistent with the agency threat framework, became stale, ultimately undermining the agency's long-term authority over device software. This Article thus uses the FDA's approach to software, spanning a quarter century, to argue that agency threats are only useful as a short-term stopgap that presages more decisive intervention.

This Article then counterposes this example to the FCC's approach to the Internet. The FCC used threats to enforce principles of Internet neutrality against Internet service providers as an initial, short-term precursor to more decisive rules and enforcement. In contrast, the FDA's initial threats became a long-term crutch with no hard law backstop. These two approaches might be superimposed onto other examples, from the Federal Aviation Administration ("FAA") screening novel aircraft designs or flight software, to the Environmental Protection Agency ("EPA") considering new sources of pollution or anti-emissions technologies, to the Securities and

23. For example, in September 2013, the FDA published another guidance explaining its approach to the latest generation of device software, embodied in mobile medical applications for smartphones and tablets (called "medical apps" or more broadly, "mobile health" applications). FDA, Mobile Medical Applications (Sept. 25, 2013) [hereinafter Mobile Medical Applications], available at http://www.fda.gov/downloads/ medicaldevices/deviceregulationandguidance/guidancedocuments/ucm263366.pdf.

24. See, e.g., Christensen et al., supra note 3; William Hanson, SMart Medicine: How the Changing Role of Doctors Will Revolutionize Health Care 3-16 (2011) (describing uses of software technology in modern medicine).

25. See infra Sections IV.A, IV.B. 
Exchange Commission ("SEC") engaging novel securities instruments or high-speed trading technologies. The FDA's own experience in relying primarily on guidance to confront novel things like genetically modified foods, nanotechnology, and xenotransplantation, demonstrates both the patterns and the stakes here. ${ }^{26}$ Somewhat counterintuitively, both the public and the innovators can benefit from earlier, more decisive regulatory interventions, per the FCC's approach to net neutrality.

The Article begins in Part II by addressing "regulatory disruption," the idea that novel technologies or business practices can disturb existing regulatory frameworks. Part III then considers agency threats as a response, drawing on the FDA's long struggle to regulate computerized devices as a model to avoid, and the FCC's recent battle for net neutrality as the model to emulate. Part IV broadens this argument and assesses normatively how agencies should address regulatory disruption. Agencies facing disruption must make four related decisions, each of which is implicated when deciding whether to use "threats": (i) when to intervene, (ii) the form that intervention should take, (iii) how durable or transitory that intervention should be, and (iv) how rigorously to monitor and sanction noncompliance. "Threats" are not just a decision about form, but also represent decisions about timing, duration, and enforcement.

This Article argues that if agencies are concerned about regulating new technologies or business practices in error, or prematurely, then they can experiment with alternative timing and enforcement methods to reduce these risks while maintaining regulatory fortitude. Agencies can experiment with binding regulation. For example, agencies might use regulatory sunsets to better calibrate how long the intervention endures. Agencies could also specify rulemaking deadlines to make good on initial threats. And citizen suits or private rights of action could help correct systematic underenforcement by resource-strapped regulators.

\section{DISRUPTIVE INNOVATION}

In 1995, Joseph Bower and Clayton Christensen introduced the idea of "disruptive technologies" that depart fundamentally from existing ones, usually by being less complicated, more accessible, and less expensive. ${ }^{27}$ Disruptive "technologies"-later broadened in the literature to disruptive

26. See, e.g., Lars Noah, Managing Biotechnology's [R]evolution: Has Guarded Enthusiasm Become Benign Neglect?, 11 VA. J.L. \& TECH., no 4, Spring 2006, at 1, 22-35, 45, 60-63.

27. Bower \& Christensen, supra note 2. 
"innovations" - undermine and then displace incumbents. ${ }^{28}$ Classic examples include the Kodak camera, Bell telephones, Sony transistor radios, the Ford Model T, and Xerox photocopiers. ${ }^{29}$ Contemporary examples include Cisco routers, Fidelity mutual funds, Google advertising, and the Southwest Airlines business model. ${ }^{30}$ In each case, the market entrant introduced an innovation that eventually, though often not immediately, changed the entire market. The innovation "disrupts" the market in unforeseen ways.

This Article merges disruption theory with theories of regulation, using the idea of disruptive innovation to consider how regulators should respond to novel technologies or business practices that do not fit comfortably within their regulatory frameworks. The innovation typically falls within a specific agency's jurisdiction, but does not fit well within the agency's regulatory schemes that contemplate more established technologies or business practices. The innovation "disrupts" the regulatory framework, not necessarily industry incumbents, as envisioned by Bower and Christensen. "Regulatory disruption" occurs, then, when the "disruptee" is the regulatory framework itself. ${ }^{31}$

Certainly, there have been iconic innovations that did not fall within an existing agency's jurisdiction, eventually prompting Congress to create entirely new agencies. For example, the birth of commercial aviation during the barnstorming 1920s coincided with the birth of the Bureau of Air Commerce, the Civil Aeronautics Authority, and other precursors to the modern Federal Aviation Administration ("FAA"). ${ }^{32}$ The parallel evolutions of the automobile industry and the U.S. interstate highway system led Congress to create the National Highway Safety Agency, the precursor to the

28. ChristensEN, supra note 2 , at XV.

29. CHRISTENSEN ET AL., supra note 3, at 7.

30. Id.

31. Daniel Gervais addresses his analysis to "inchoate" technologies, which are fledgling technologies that have yet to mature. He does not focus his analysis explicitly on "disruptive" innovations, although he also seems to contemplate technologies that do not fit well into existing regulatory frameworks. See Gervais, supra note 11, at 671-72.

32. See generally Miranda Anger, International Aviation Safety: An Examination of the U.S., EU, and the Developing World, 72 J. AIR L. \& COM. 141, 142-49 (2007); Frederick A. Ballard, Federal Regulation of Aviation, 60 HARV. L. REV. 1235 (1947). For a fascinating history of the government's unique role in innovation in the commercial airline industry, see David C. Mowery \& Nathan Rosenberg, The Commercial Aircraft Industry, in GovernmenT AND TeChnical Progress: A Cross-Industry Analysis 101-61 (Richard R. Nelson ed., 1982). 
National Highway Traffic Safety Administration ("NHTSA"), and the Department of Transportation. ${ }^{33}$

But this Article is not concerned with innovations that have no regulatory "home," as these generally require congressional intervention to assign jurisdiction. Agencies cannot address them sua sponte. ${ }^{34}$ The U.S. regulatory state has aged out of its formative years, when Congress created most modern regulatory agencies. ${ }^{35}$ Today, there are hundreds of federal agencies, departments, and commissions, ${ }^{36}$ many of which enjoy sweeping jurisdiction. For that reason, few innovations today will emerge without a regulatory "home" (or even multiple "homes") completely beyond every agency's jurisdiction. The contemporary challenge, then, is how existing agencies can confront these innovations given their broad but sometimes inert statutory frameworks.

33. Ralph Nader's famous book, UnSAFE AT ANY SpEED: THE DESIGNeD-IN DANGERS OF THE AMERICAN AUTOMOBILE (1965), amplified growing public demand for auto safety regulation, leading Congress to pass the Highway Safety Act of 1966, Pub. L. No. 89-564, 80 Stat. 731 (codified as amended at 23 U.S.C. SS $401-404$ (2012)), the National Traffic and Motor Vehicle Safety Act of 1966, Pub. L. No. 89-563, 80 Stat. 718 (codified as amended at 49 U.S.C. SS 30,101-30,126, 30,141-30,147, 30,161-30,169 (2012)), and the Department of Transportation Act, Pub. L. No. 89-670, 80 Stat. 931 (1966). In parallel, Congress confronted pollution by motor vehicles with the Motor Vehicle Air Pollution Control Act, Pub. L. No. 87-272, 79 Stat. 992 (1965), which vested regulatory authority with the U.S. Department of Health, Education, and Welfare ("HEW"). In 1969, Congress created the Council on Environmental Quality ("CEQ") with the National Environmental Policy Act of 1969, Pub. L. No. 91-190, 83 Stat. 852 (codified as amended at 42 U.S.C. \$S 4321-4347), which was later reorganized by executive order into the Environmental Protection Agency (EPA), Reorganization Plan No. 3 of 1970, 3 C.F.R. 1072 (1966-1970), reprinted in 84 Stat. 2086 (1970). For a history of the government's role in facilitating innovation in the automobile industry, see Lawrence J. White, The Motor Vehicle Industry, in GOVERnMENT AND TECHNICAL PROGRESS: A CROSS-INDUSTRY ANALYSIS, supra note 32, at 411-50.

34. See FDA v. Brown \& Williamson Tobacco Corp., 529 U.S. 120 (2000) (striking down the FDA's attempt to regulate tobacco products without explicit congressional authority to do so).

35. See generally Jerry L. Mashaw, Federal Administration and Administrative Law in the Gilded Age, 119 YALE L.J. 1362 (2010) (describing an early history of administrative agencies); Jerry L. Mashaw, Administration and "the Democracy": Administrative Law from Jackson to Lincoln, 18291861, 117 YALE L.J. 1568 (2008); Jerry L. Mashaw, Reluctant Nationalists: Federal Administration and Administrative Law in the Republican Era, 1801-1829, 116 YALE L.J. 1636 (2007); Jerry L. Mashaw, Recovering American Administrative Law: Federalist Foundations, 1787-1801, 115 YALE L.J. 1256 (2006); Robert L. Rabin, Federal Regulation in Historical Perspective, 38 STAN. L. REV. 1189 (1986) (describing a broader period-by-period history of federal regulation).

36. See Federal Agencies and Commissions, THE WHITE House, http://www.white house.gov/our-government/federal-agencies-and-commissions (last visited Sept. 19, 2013). 
Perhaps the best modern example is the Internet. Since 1934, the FCC has had jurisdiction over communications networks. ${ }^{37}$ But the Communications Act addressed a world of circuit-switching on telephone lines operated by monopoly "common carriers," not the future world of decentralized, digitized, packet-switching run by a constellation of smaller Internet service providers. ${ }^{38}$ When this world began to emerge in the $1980 \mathrm{~s}$ and 1990s, the FCC "self-consciously adopted a policy of non-regulation." 39 But the FCC's posture of separating "telecommunications services" from "information services" became less and less tenable as the Internet began to mature in the 1990s. ${ }^{40}$ By then, it was clear that Internet service fell within the FCC's jurisdiction. But it did not square well with the FCC's longstanding framework. ${ }^{41}$

Another immediate example of disruptive innovation is the avalanche of novel securities instruments that contributed to the 2008 financial crisis. For years, financial firms had been experimenting with new and sometimes exotic securities products, particularly over-the-counter derivatives like mortgagebacked securities, credit default swaps, and collateralized debt obligations. ${ }^{42}$ In the 1990s, the Commodities Futures Trading Commission ("CFTC") considered using its existing jurisdiction to regulate the derivatives market, until Congress intervened to bar it, at the behest of key regulators like Federal Reserve chairman Alan Greenspan and Treasury Secretary Robert

37. Communications Act of 1934, Pub. L. No. 73-416, 48 Stat. 1064, 1064 (codified as amended in scattered sections of 47 U.S.C. (2012)) ("An Act to provide for the regulation of interstate and foreign communication by wire or radio, and for other purposes.").

38. See Jonathan Weinberg, The Internet and "Telecommunications Services," Universal Service Mechanisms, Access Charges, and Other Flotsam of the Regulatory System, 16 YALE J. ON REG. 211, 211-12, 215-18 (1999) (juxtaposing Internet technologies with the regulatory framework created by the Communications Act of 1934, which created the FCC).

39. Philip J. Weiser, The Future of Internet Regulation, 43 UC DAVIS L. REV. 529, 531 (2009) (internal quotations omitted).

40. See Kevin Werbach, The Network Utility, 60 DuKE L.J. 1761, 1763-64 (2011); see also Weinberg, supra note 38, at 212, 232-34; Weiser, The Future of Internet Regulation, supra note 39, at 531.

41. See infra Section III.C (discussing the FCC's response in further detail).

42. See Financial Crisis Inquiry Commission, The Financial Crisis Inquiry REPORT, at xxiv (2011), available at http://fcic-static.law.stanford.edu/cdn_media/fcicreports/fcic_final_report_full.pdf [hereinafter FCIC FINAL REPORT] (reviewing financial products and their contribution to the financial collapse of 2008); see also Brooksley Born, Foreword: Deregulation: A Major Cause of the Financial Crisis, 5 HARV. L. \& POL'Y REV. 231 (2011). For an entertaining popular account of these novel securities and those who created them (and the few that actually understood them), see MICHAEL LEWIS, THE BIG SHORT: INSIDE THE DOOMSDAY MACHINE (2010). 
Rubin. $^{43}$ Greenspan, a well-known laissez faire economist, pushed deregulation and self-regulation in the derivatives market, strongly resisting the CFTC's efforts to act on concerns that the market posed broad, systemic risks. ${ }^{44}$ In the years leading up to the housing and stock market crash in 2008, the derivatives market would balloon to $\$ 673$ trillion in notional amount. ${ }^{45}$

In the wake of the economic crisis, Congress created the Financial Crisis Inquiry Commission ("FCIC") to investigate the root causes of the financial collapse. $^{46}$ The FCIC attributed the collapse in part to the weak response by regulators to these novel financial products and practices. For example, the Federal Reserve Board had refused to use its authority to regulate aggressive new mortgage lending practices. ${ }^{47}$ The Securities and Exchange Commission ("SEC") had failed to enforce disclosure requirements for mortgage-backed securities. ${ }^{48}$ Congress had pushed to deregulate novel over-the-counter derivatives. ${ }^{49}$ And regulators like the SEC, the Office of the Comptroller of the Currency ("OCC"), and the Office of Thrift Supervision ("OTS") exerted only superficial oversight of the banks engaged in these activities. ${ }^{50}$ The FCIC's final report found that "[t]echnology has transformed the efficiency, speed, and complexity of financial instruments and transactions," but that the United States "had a 21st-century financial system with 19thcentury safeguards." 51

43. See Commodity Futures Modernization Act of 2000, Pub. L. No. 106-554, 114 Stat. 2763 (codified as amended in scattered sections of 7, 11, 12, 15 U.S.C.). Before that, Congress imposed a moratorium on the CFTC action. Omnibus Consolidated and Emergency Supplemental Appropriations Act, Pub. L. No. 105-277 \ 760, 112 Stat. 2681-1, 2681-35 (1998). For a description of the role Rubin and Greenspan, among others, played in this matter, see FCIC FINAL REPORT, supra note 42, at 47. The over-the-counter derivatives market is one innovation that Wu concedes might have benefited from more traditional early regulation. Wu, supra note 11 , at 1850.

44. Peter S. Goodman, Taking a Hard New Look at a Greenspan Legacy, N.Y. TimeS, Oct. 9, 2008, http://www.nytimes.com/2008/10/09/business/economy/09greenspan.html (quoting congressional testimony of Brooksley Born, then chair of the CFTC, that the opaque derivatives market could "threaten our regulated markets or, indeed, our economy without any federal agency knowing about it."); Born, supra note 42, at 236-38 (quoting Greenspan's testimony to Congress urging that regulation was unnecessary for over-the-counter derivatives).

45. FCIC FINAL REPORT, supra note 42, at xxiv.

46. Fraud Enforcement and Recovery Act of 2009, Pub. L. No. 111-21 §5(a), 123 Stat. $1617,1625$.

47. FCIC FINAL REPORT, supra note 42, at xvii; Born, supra note 42, at 234-35.

48. FCIC FINAL REPORT, supra note 42, at 169-70; Born, supra note 42, at 235-36.

49. FCIC FINAL REPORT, supra note 42, at xxiv-xxv; Born, supra note 42, at 236-38.

50. FCIC FINAL REPORT, supra note 42, at xviii, 150-54, 173-174, 302-04; Born, supra note 42 , at 238-42.

51. FCIC FINAL REPORT, supra note 42, at xv, xvii, xx. 
These stories tell the modern predicament: how do regulators with broad statutory authority manage innovations as they mature, and as their problems become apparent?

\section{EMPTY THREATS?}

If certain innovations do not square well with existing regulatory frameworks, how should agencies respond, sans congressional intervention? This Part first considers the argument that agencies should rely on informal threats rather than more traditional modes of regulation. It then demonstrates how the FDA took precisely this approach with computerized devices twenty-five years ago, which led to suboptimal regulation of increasingly ubiquitous and dangerous products. This story cautions against over-relying on regulatory threats. Part III concludes by counterposing the FDA's approach to software with the FCC's use of threats to address Internet networks, which was disciplined by early enforcement and rulemaking to codify its threats. Unlike the FDA, the FCC did not over-rely on threats.

\section{A. AgEnCy Threats}

The agency threat framework argues that federal agencies should use informal "threats" against regulated industries under conditions of "high uncertainty." 52 For example, an agency might announce via guidance document, warning letter, or press release that it will take action against companies that employ novel technologies or business practices in a certain way. ${ }^{53}$ But this type of regulatory elasticity, as demonstrated below, can harden into a long-term default position, leading to suboptimal regulation if not disciplined in some way.

An agency makes a "threat" when it gives "at least some warning of agency action related to either ongoing or planned behavior." 54 Agencies can package threats in many forms-guidance documents, interpretive rules, warning letters, press releases, official speeches, and even private meetings with regulated firms. ${ }^{55}$ Threats can be very public, as a press release, or very

52. Wu, supra note 11, at 1848 (defining "high uncertainty" as scenarios "in which alternative future states of the world do not occur with quantifiable probability").

53. Id. at $1841,1844$.

54. Id. at 1844.

55. Id. Some of these vehicles themselves come in many forms. For example, guidance documents can include enforcement guidelines, policy statements, interpretive rules and memoranda, agency staff manuals and circulars, private ruling letters, informal advice, etc. See Final Bulletin, Agency Good Guidance Practices, 72 Fed. Reg. 3432, 3434 (Jan. 25, 2007); M. Elizabeth Magill, Agency Choice of Policymaking Form, 71 U. CHI. L. REV. 1383, 1386, 1391 
private, as a face-to-face meeting. ${ }^{56}$ Either way, the threat specifies behavior that the agency either desires or forbids. ${ }^{57}$ Invoking a notorious example, Wu gives a nod to Don Corleone's use of threats in The Godfather. ${ }^{58}$

Regardless of their wrapping, threats are informal rather than formal, soft law rather than binding hard law, and are issued without much procedure (though they may be accompanied by quite a bit of ceremony). ${ }^{59}$ This, indeed, is their appeal. Threats can issue without notice and comment or other procedural hurdles required by the Administrative Procedure Act ("APA") or other statutes. ${ }^{60}$ As such, threats serve as a third alternative to rulemaking and adjudication, the two classic modes of regulation. ${ }^{61}$ According to $\mathrm{Wu}$, Peter Strauss, and other advocates of informal agency action, threats occupy "an important element in the hierarchy of agency law." ${ }^{62}$ On this I agree.

$\mathrm{Wu}$ also contemplates threats as being unenforceable by agencies, ${ }^{63}$ though ambiguity on this point seems to be the point. Otherwise, what is the agency threatening? The agency threat specifies either desired or forbidden behavior, and at least hints at potential repercussions. Threats, in short, are assertions that the agency will do something at some point given certain triggering activities. A threat that is unenforceable on its face would not seem to appeal to many agencies.

(2004). A 2007 Executive Order by the Bush administration defined "guidance document" as "an agency statement of general applicability and future effect, other than a regulatory action, that sets forth a policy on a statutory, regulatory, or technical issue or an interpretation of a statutory or regulatory issue." See Exec. Order No. 13,422, 3 C.F.R. 19192 (2007) (rescinded by Exec. Order No. 13,497, 3 C.F.R. 218 (2010)).

56. Wu, supra note 11, at 1844.

57. Id.

58. Wu stops short of suggesting that agencies rely on some of the more aggressive tactics used by the mafia. See id. at 1857 (referencing THE GODFATHER (Paramount Pictures 1972)).

59. Id. at 1844. "Soft law" is described in Jacob E. Gersen \& Eric A. Posner, Soft Law: Lessons from Congressional Practice, 61 STAN. L. REV. 573 (2008).

60. See, e.g., Robert A. Anthony, Interpretive Rules, Policy Statements, Guidances, Manuals, and the Like — Should Federal Agencies Use Them to Bind the Public?, 41 DuKE L.J. 1311, 1328, 133435 (1992); Nathan Cortez, Adverse Publicity by Administrative Agencies in the Internet Era, 2011 BYU L. REV. 1371, 1380 (2011); Lars Noah, Administrative Arm-Twisting in the Shadow of Congressional Delegations of Authority, 1997 WIS. L. REV. 873, 874-76 (1997); Lars Noah, The Little Agency That Could (Act with Indifference to Constitutional and Statutory Strictures), 93 CORNELL L. REV. 901, 904-05 (2008).

61. Wu, supra note 11, at 1841.

62. Gersen \& Posner, supra note 59, at 626; Peter L. Strauss, Publication Rules in the Rulemaking Spectrum: Assuring Proper Respect for an Essential Element, 53 ADMIN. L. REV. 803, 804 (2001); Wu, supra note 11, at 1847; David Zaring, Best Practices, 81 N.Y.U. L. REV. 294, 294 (2006).

63. See Wu, supra note 11, at 1846. 
Threats are useful, according to their proponents, under conditions of high uncertainty, and for dynamic rather than static states of industry. ${ }^{64}$ Thus, for relatively stable industries in which business models, practices, and technologies are relatively well settled, agencies have enough information to regulate with certainty. ${ }^{65}$ Legally binding rules make sense. Agencies can activate the lumbering machinery of rulemaking or adjudication without worrying that the effort will be for naught, or that "law" they produce will soon be obsolete. But in dynamic industries-characterized by disruptive innovation, unexpected market entries, new business models, and other exogenous shocks_-agencies may lack sufficient information to regulate with certainty. ${ }^{66}$ Doing so risks creating rules that are miscalibrated, or premature, or both. ${ }^{67}$

According to the threat framework, agencies face three choices when confronting dynamic states of industry: make law, make threats, or do nothing. ${ }^{68}$ Again, making law via traditional rulemaking or adjudication can be premature or simply may generate flawed rules. And somewhat ironically, making law may create more uncertainty by triggering judicial challenges that can take years to resolve. ${ }^{69}$ Doing nothing, or waiting, can also be undesirable because the industry may develop outside the public eye, and without considering the public interest. ${ }^{70}$ Moreover, as the industry matures, the more settled its norms and business practices will become, which can be hard to reverse later. ${ }^{71}$

Threats, the argument goes, allow agencies to oversee the formative years of an industry without suffocating it. $^{72}$ Agency threats themselves can

64. Id. at 1848 .

65. Id.

66. Id. at 1849 .

67. Id. Although Wu does not discuss Clayton Christensen's "disruptive innovation" framework in Agency Threats, supra note 11, he does address it in a separate work. See Wu, THE MASTER SwITCH, supra note 12, at 20.

68. Wu, supra note 11, at 1848-49. This list generally parallels the four choices David Super identifies when agencies must make decisions that appear to be unusually costly: (i) devote the resources necessary to make the decision, (ii) make a low-quality decision based on the limited decisional inputs it can muster, (iii) postpone a decision to when it has better decisional inputs, or (iv) do nothing. David A. Super, Against Flexibility, 96 Cornell L. REV. 1375, 1407 (2011).

69. Wu, supra note 11 , at 1849.

70. Id. at 1850. Gervais, conversely, argues that social norms and sometimes the technology itself will fill the regulatory void. Gervais, supra note 11, at 668 .

71. Wu, supra note 11, at 1842, 1854.

72. Id. at 1851 . 
generate a public debate, which often contemplates the public interest. ${ }^{73}$ And the lack of formality makes the threat quicker to issue and more flexible than rulemaking or adjudication. ${ }^{74}$ If the threat turns out to be too harsh, or not harsh enough, the agency can easily retreat or recalibrate.

Proponents argue that the criticisms of agency threats are overblown. Rather than being a procedural end-run around the APA, an amplification of statutory authority, a way to skirt judicial review, or even an affront to the rule of law itself, ${ }^{75}$ agency threats are precisely what agencies should use in conditions of high uncertainty. According to $\mathrm{Wu}$, we should stop worrying and learn to love agency threats. ${ }^{76}$

This Article tests this argument by looking at two instances of agencies relying on threats in responding to disruptive technologies: the FDA's response to software and the FCC's response to the Internet. It is striking how closely the FDA's approach to software fits the threat framework. The medical device software industry has always been relatively dynamic. ${ }^{77}$ The pace of innovation seems to be forever quickening, not abating, as evidenced by the latest generation of medical software for mobile devices. ${ }^{78}$ To say that the FDA is facing conditions of high uncertainty is to risk understatement. ${ }^{79}$ Moreover, frequently we hear the chorus that FDA rulemaking for software would be premature, due to the agency's lack of expertise, its lack of resources, and the state of the industry. ${ }^{80}$

73. Id. Gervais worries that quickly-developing social norms will evolve to circumvent any new regulatory framework. Gervais, supra note 11, at 673 .

74. Wu, supra note 11 , at 1851.

75. Id. at 1846-47. Wu focuses particular attention on Lars Noah's criticisms, supra note 60 , which survey the range of problems and recent examples of abuse.

76. Wu, supra note 11, at 1842; see also Nicolas P. Terry, Prescriptions Sans Frontières (or How I Stopped Worrying About Viagra on the Web but Grew Concerned About the Future of Healthcare Delivery), 4 Yale J. Health Pol’y L. \& Ethics 183 (2004); Dr. Strangelove or: How I LeARned to Stop Worrying AND Love the Bomb (Columbia Pictures 1964).

77. Nathan Cortez, Analog Agency in a Digital World (unpublished manuscript) (on file with author) (tracing the development of early medical device software to the present day, and the FDA's regulatory response).

78. See, e.g., Nathan Cortez, The Mobile Health Revolution, 47 UC DAVIS L. REV. 1173 (2014) (surveying mobile medical applications and other mobile health technologies and examining their significance).

79. The FDA itself emphasizes the high uncertainty in its guidance for mobile medical applications, noting the "extensive variety of actual and potential functions of mobile apps, the rapid pace of innovation in mobile apps, and the potential benefits and risks to public health represented by these apps." Mobile Medical Applications, supra note 23, at 4.

80. See, e.g., FDA Public Workshop-Mobile Medical Applications Draft Guidance, FDA, (Sept. 12-13, 2011), http://www.fda.gov/MedicalDevices/NewsEvents/WorkshopsConferences/ ucm267821.htm (last visited Oct. 29, 2013) [hereinafter FDA Public Workshop] (transcripts available at http://www.fda.gov/MedicalDevices/NewsEvents/WorkshopsConferences/uc 
Consistent with the agency threat framework, the FDA did not make law. Nor did it do nothing. It published several guidance documents. It made threats. Moreover, these threats have at times generated public debate, sometimes even including lengthy public comment periods. ${ }^{81}$ Finally, the latest wave of medical software developers seems to prefer some guidance to none, ${ }^{82}$ although unsurprisingly it wants more clarity. In short, the FDA's approach to software over the last twenty-five years demonstrates how an agency relied on threats in precisely the circumstances described by Wu.

\section{B. The FDA AND THE QUARTER-CENTURY-LONG THREAT}

Overburdened agencies like the FDA have long embraced informal threats. But there can be too much of a good thing. For twenty-five years, the FDA has relied on threats to address software in medical devices. This history cautions that threats can become stale and even counterproductive.

As with many regulatory interventions, the FDA's foray into device software was prompted by tragedy. ${ }^{83}$ The story begins in 1985, when a Canadian company began selling the first therapeutic radiation machines controlled primarily by software. ${ }^{84}$ Between 1985 and 1987, the machines massively over-radiated several patients in the United States and Canada, killing at least six. ${ }^{85}$ The injuries were attributed to various software design flaws and user errors. ${ }^{86}$ When the FDA investigated these incidents, it required the manufacturer to make certain corrections, which were not fully

m275908.htm and http://www.fda.gov/MedicalDevices/NewsEvents/WorkshopsConfere nces/ucm275909.htm).

81. Id.

82. The mHealth Regulatory Coalition objected to the Bennett-Hatch amendment to the FDA user fee bill that would have prohibited FDA from finalizing its Draft Guidance for eighteen months. Letter from mHealth Regulatory Coalition to Senators Enzi and Harkin (May 17, 2012), http://mhealthregulatorycoalition.org/wp-content/uploads/2010/ 06/MRC-Letter-to-Senate-HELP-Committee-on-Proposed-Moratorium-FINAL.pdf.

83. The tragedy over thalidomide helped prompt the 1962 Drug Amendments. CARPENTER, supra note 19, at 256-60; J. Richard Crout et al., FDA's Role in the Pathway to Safe and Effective Drugs, in FDA: A CENTURY OF CONSUMER PROTECTION, supra note 18, at 159, 168-69.

84. See generally Nancy G. Leveson, Medical Devices: The Therac-25, in SAFEWARE: SYSTEM SAFETY AND COMPUTERS 515 app. A (1995) (providing a comprehensive story of the Therac-25 saga). The FDA had begun considering software before the Therac-25, as shown by its letters in response to congressional committees considering computers in medicine. See Information Technologies in the Health Care System, Hearing before the Subcomm. on Investigations and Oversight of the H. Comm. on Sci. and Tech., 99th Cong. 196-204 (1986). But the Therac-25 saga seemed to push the agency towards announcing a policy towards software.

85. Leveson, supra note 84 , at 515.

86. Id. 
implemented until two years later, after a recall. ${ }^{87}$ Yet, at the time, the FDA's response was considered "impressive," given that it had no policy for medical software. ${ }^{88}$

In 1986, FDA Commissioner Frank Young said in a speech that the agency would approach device software with the "least regulation consistent with the requirements of public health and safety." "This speech represented the first threat, though the threat was a soft, imprecise one. In 1987, the FDA published its first draft policy on software, explaining which types of software the agency would and would not regulate, and which regulatory requirements might apply. ${ }^{90}$

In 1989, the FDA updated the document, which became known as the "Draft Software Policy." The policy confirmed that the FDA's "basic philosophy for computer products" was "to apply the least degree of regulatory control necessary to provide reasonable assurance of safety and effectiveness." ${ }^{22}$ Like the 1987 version, the 1989 policy delineated which computer products the agency would and would not regulate. ${ }^{93}$ It clarified how these new technologies might fit into the statutory definition of "device," which Congress wrote in 1976 when no one could have imagined today's versions. ${ }^{94}$ Together, the 1987 and 1989 draft software policies constituted "threats," consistent with the framework.

Since that time, the FDA's approach to computerized medical devices has been the archetype of regulatory minimalism. The agency never finalized the 1989 Draft Software Policy; in fact, the FDA withdrew it without explanation in $2005 .^{.5}$ In the absence of legally binding rules, lawyers have

87. Id. at $525,544-48$.

88. Id. at 553 .

89. FDA \& National Library of Medicine, Software Policy Workshop (Sept. 3-4, 1996), reprinted in FOOD AND DRUG LAw INSTITUTE, BiomedicAl SOFTWARE REgUlation 403 (Thomas E. Colonna \& Jonathan S. Helfgott eds., 2009) [hereinafter FDA \& NLM, 1996 Software Policy Workshop].

90. 1987 Notice of Draft Policy, supra note 21; see also Medical Devices; Medical Software Devices; Notice of Public Workshop, 61 Fed. Reg. 36,886 (July 15, 1996). The FDA had begun crafting the policy in 1985. See FDA \& NLM, 1996 Software Policy Workshop, supra note 89 , at 403.

91. 1989 Draft Software Policy, supra note 21; see Mobile Medical Applications, supra note 23 , at 6 .

92. E. Stewart Crumpler \& Harvey Rudolph, FDA Software Policy and Regulation of Medical Device Software, 52 FOOD \& DRUG L.J. 511, 513 (1997).

93. 1989 FDA Draft Software Policy, supra note 21.

94. Medical Device Amendments of 1976, Pub. L. No. 94-295 (1976) (codified as amended at 21 U.S.C. $\int 321$ (2012)).

95. Annual Comprehensive List of Guidance Documents at the Food and Drug Administration, 70 Fed. Reg. 824,890 (Jan. 5, 2005). 
had to advise clients based largely on the 1989 draft policy, even after the FDA withdrew the policy. The agency did pre-clear discrete software products on a case-by-case basis, which could serve as precedent for similar products. ${ }^{96}$ But this piecemeal approach fell far short of establishing a definitive, cohesive philosophy towards software that companies could use to predict their regulatory obligations.

Ironically, after the FDA withdrew the 1989 guidance, it explained that "it would be impractical to prepare an overarching software policy to address all of the issues related to the regulation of all medical devices containing software" because "the use of computer and software products as medical devices grew exponentially and the types of products diversified and became more complex." 97 Thus, rather than providing more oversight as medical technology matured-during a profound computer revolution-the FDA provided less.

By and large, the FDA has avoided proceeding by rule here. It has promulgated very few prospective regulations governing software, and what little it has done addresses relatively low-risk devices. ${ }^{98}$ For example, in 2011, the FDA finalized a rule governing medical device data systems. But these represent only a narrow slice of low-risk products that merely transfer, store, display, or convert medical device data, without doing much else. ${ }^{99}$ Periodically, in the preambles to final rules, the FDA will acknowledge computer products. For example, when finalizing its Quality Systems Regulation ("QSR") for devices in 1996, the FDA observed that software design flaws and the failure to validate software after maintenance were the most common source of errors. ${ }^{100}$ The QSR, which establishes good manufacturing practices for devices, ${ }^{101}$ has been perhaps the one area in

96. For example, the FDA has created dozens of regulatory categories for devices that incorporate software, including medical calculators, cameras, lights, magnifiers, microscopes, monitors, recorders, reminders, scales, surgical tools, and a host of data systems that store, display, and manipulate data. Mobile Medical Applications, supra note 23, at 29-31 (listing distinct device categories codified by FDA).

97. FDA, Draft Guidance for Industry and Food and Drug Administration Staff: Mobile Medical Applications, 5 (July 11, 2011) [hereinafter 2011 Mobile Medical Applications Draft] (on file with author) (superseded by Mobile Medical Applications, supra note 23) (referring to the 2005 withdrawal of the 1989 Draft Software Policy).

98. For example, in 2011, the agency promulgated a rule classifying devices that electronically display, store, transfer, or convert medical device data, known as Medical Device Data Systems ("MDDS"). 76 Fed. Reg. 8637 (Feb. 15, 2011) (codified at 21 C.F.R. $\left.\int 880.6310(2013)\right)$.

99. See 21 C.F.R. $\int 880.6310($ a); 76 Fed. Reg. 8643-44 (Feb. 15, 2011).

100. Medical Devices; Current Good Manufacturing Practice (“CGMP”), 61 Fed. Reg. 52,602, 52,617, 52,620 (Oct. 7, 1996).

101. 21 C.F.R. $\int 820.1$ (2013). 
which the FDA has provided firm standards for software. But the QSR is notable for giving manufacturers significant flexibility to design and manufacture devices according to customized specifications. ${ }^{102}$ This is both a strength and a weakness - a strength in recognizing the diversity of medical devices and the implausibility of generating one-size-fits-all standards, but a weakness in decentralizing standards and delegating significant discretion to regulated firms. Of course, the FDA relies on guidance to explain how the QSR applies to software. ${ }^{103}$

Indeed, the FDA heavily relies on guidance to oversee software. Agency documents that summarize the FDA's approach generally cite to the same cluster of five guidances. ${ }^{104}$ Together, these documents form a cascade of quasi-regulation, recommendations, and "current thinking," 105 but offer few firm rules. Software does not stand on terra firma with the FDA. Looking back, the 1987 document was like the gateway drug that led to guidance after guidance for the next twenty-five years.

Unfortunately, the FDA's response to software has not been commensurate with how ubiquitous and critical to patient safety software has become. Widespread problems with device software persist. For example, between 2009 and 2011, the New York. Times documented several hundred catastrophic injuries caused by software and user errors related to the newest generation of radiation machines. ${ }^{106}$ The incidents bear striking similarity to the problems with radiation software that originally prompted the FDA's

102. See Medical Devices Quality System (QS) Regulation/Medical Device Good Manufacturing Practices, FDA, http://www.fda.gov/MedicalDevices/DeviceRegulationandGuidance/Post marketRequirements/QualitySystemsRegulations/default.htm (last updated Apr. 28, 2011).

103. See, e.g., FDA, General Principles of Software Validation (Jan. 11, 2002), available at http://www.fda.gov/downloads/MedicalDevices/DeviceRegulation

andGuidance/GuidanceDocuments/ucm085371.pdf.

104. See FDA, Cybersecurity for Networked Medical Devices Containing Off-the-Shelf (OTS) Software (Jan. 14, 2005), available at http://www.fda.gov/downloads/ MedicalDevices/DeviceRegulationandGuidance/GuidanceDocuments/ucm077823.pdf;

FDA, Guidance for the Content of Premarket Submissions for Software Contained in Medical Devices (May 11, 2005), available at http://www.fda.gov/downloads/medical devices/deviceregulationandguidance/guidancedocuments/ucm089593.pdf; FDA, General Principles of Software Validation, supra note 103; Guidance for Industry, FDA Reviewers and Compliance on Off-The-Shelf Software Use in Medical Devices (Sept. 9, 1999), available at http://www.fda.gov/downloads/MedicalDevices/DeviceRegulationandGuidance/Gu idanceDocuments/ucm073779.pdf; FDA, Design Control Guidance for Medical Device Manufacturers (Mar. 11, 1997), available at http://www.fda.gov/downloads/Medical Devices/DeviceRegulationandGuidance/GuidanceDocuments/ucm070642.pdf.

105. See, e.g., FDA, supra note 103 , at 1 .

106. See, e.g., Radiation Boom, N.Y. TIMES, http://topics.nytimes.com/top/news/ us/series/radiation_boom/index.html (last visited Oct. 10, 2013) (linking to twenty-six articles in the series on medical radiation by Walt Bogdanich). 
intervention two decades earlier. In one case, a hospital in Manhattan exposed a cancer patient to fatal doses of radiation for three consecutive days after the software repeatedly crashed. ${ }^{107}$ The patient died two years later. ${ }^{108}$ In another case, a Brooklyn hospital administered three and a half times the prescribed dose of radiation to a breast cancer patient for twenty-seven days due to user errors and misprogrammed software. ${ }^{109}$ The New York Times documented hundreds of similar mistakes, ${ }^{110}$ with one expert estimating that one in twenty radiation patients nationwide will suffer injury. ${ }^{111}$

Unfortunately, the FDA's posture towards software is reactive rather than proactive. To wit, the FDA subsequently investigated these radiation software failures reported by the New York Times, but only after they generated national attention. ${ }^{112}$

Yet, the FDA seems to be generally aware of the dangers posed by software products. In February 2010, the FDA revealed during a public meeting that it had received voluntary reports of 260 malfunctions, forty-four injuries, and six deaths related to health information technologies. ${ }^{113}$ But because these were voluntary reports, and because even the FDA's mandatory reporting requirements suffer from dramatic under-reporting, the real numbers are no doubt much higher. ${ }^{114}$

These injuries are the byproducts of medical innovation. As alluring as medical innovation is, it is not an unmitigated good. The role of regulators like the FDA is to facilitate the benefits of new technologies while managing

107. Walt Bogdanich, Radiation Offers New Cures, and Ways to Do Harm, N.Y. TIMES, Jan. 23, 2010, http://www.nytimes.com/2010/01/24/health/24radiation.html.

108. Id.

109. Id.

110. Id. ("Over the previous eight years, despite hundreds of mistakes, the state issued just three fines against radiotherapy centers, the largest of which was \$8,000.”); Walt Bogdanich, As Technology Surges, Radiation Safeguards Lag, N.Y. TimeS, Jan. 27, 2010, http://www.nytimes.com/2010/01/27/us/27radiation.html.

111. Bogdanich, supra note 107 (quoting Dr. John J. Feldmeier of the University of Toledo).

112. Id.

113. Testimony of Jeffrey Shuren, Director, FDA's Center for Devices and Radiological Health, Health Information Technology ("HIT") Policy Committee, Adoption/Certification Workgroup (Feb. 25, 2010) (on file with author).

114. See Edward M. Basile \& Beverly H. Lorell, The Food and Drug Administration's Regulation of Risk Disclosure for Implantable Cardioverter Defibrillators: Has Technology Outpaced the Agency's Regulatory Framework?, 61 FOOD \& DRUG L.J. 251, 257-58 (2006) ("The [FDA] estimates that as few as one in every 100 medical device adverse events actually is reported to [the] FDA, although there is no hard data to support this estimate."). 
their risks. ${ }^{115}$ Doing so should support rather than undermine long-term markets for the technologies, preserve consumer trust, and level the playing field among competitors. Facilitating new technologies need not be in tension with managing their risks. The challenge for regulators is pursuing both during early periods of high uncertainty.

\section{THE FCC AND THE SIX-YEAR-LONG THREAT}

In contrast to the FDA's quarter-century-long threat, the FCC took a more disciplined approach when confronted with its own disruptive innovation. Unlike the FDA's initial "threat" in 1987, which lingered for decades, the FCC's initial "threat" in 2004-warning Internet service providers to maintain net neutrality ${ }^{116}$ - was quickly reinforced by enforcement and, ultimately, by rulemaking just six years later. The differences here are instructive. Like the FDA, the FCC was confronted with a new technology that did not square well with its existing regulatory framework. And like the FDA's early posture towards software, the FCC's early posture towards the Internet was one of benign neglect. ${ }^{117}$ The lack of high-profile problems seemed to justify this approach, ${ }^{118}$ perhaps as it also justified FDA's early stance towards software.

The Internet developed gradually as a government and academic network between the late 1960s and the late 1980s. ${ }^{119}$ Since 1934, jurisdiction over communications networks has resided with the FCC. ${ }^{120}$ As early as 1966 , the FCC foresaw the potential convergence between computers and communications, initiating what it called the Computer I inquiry to study how

115. For example, the Federal Food, Drug, and Cosmetic Act authorizes the FDA to pre-approve only new drugs that are safe and effective, which requires balancing their risks and benefits. 21 U.S.C. $\int 355$ (2012).

116. Wu, supra note 11 , at 1844-45, 1852 n.41. Wu originally coined the phrase "net neutrality." See Tim Wu, Network Neutrality, Broadband Discrimination, 2 J. Telecom. \& HigH TECH. L. 141 (2003).

117. Weiser, The Future of Internet Regulation, supra note 39, at 531, 533 ("To date, the Internet has developed outside of the FCC's traditional regulatory model, enjoying freedom from regulatory oversight.”).

118. Id. at 537.

119. See generally JANET ABBATE, INVENTING THE INTERNET (1999) (providing a detailed historical account of the Internet); A Brief History of the Internet \& Related Networks, INTERNET SOCIETY, http://www.internetsociety.org/internet/what-internet/history-internet/ brief-history-internet-related-networks (last visited Oct. 10, 2013) (providing a briefer history). For a compelling account of the government support required to develop the Internet and personal computing, see Steve Bickerstaff, Shackles on the Giant: How the Federal Government Created Microsoft, Personal Computers, and the Internet, 78 TEX. L. REV. 1 (1999).

120. Communications Act of 1934, Pub. L. No. 73-416, 48 Stat. 1064 (codified as amended in scattered sections of 47 U.S.C.) ("An Act to provide for the regulation of interstate and foreign communication by wire or radio, and for other purposes."). 
computers might both operate on and replicate traditional telephone networks. ${ }^{121}$ As a result of the inquiry, the FCC "chose to quarantine data processing from regulated telecommunications, rather than tackle the public policy considerations of the nascent computer utility directly."122

During the twentieth century, federal communications law developed discrete regulatory regimes for discrete services, such as telephony, broadcast television, cable television, and satellite. ${ }^{123}$ Internet Protocol transmissions did not fit neatly, if at all, into these regulatory categories. ${ }^{124}$ The FCC's regulatory framework, based on the hoary Communications Act of 1934, contemplated a world of circuit-switching on legacy telephone lines run by monopoly "common carriers"; it did not anticipate (how could it?) the decentralized, digitized, packet-switching Internet that later emerged. ${ }^{125}$

During the 1980s and 1990s, the FCC "self-consciously adopted a policy of non-regulation toward the Internet during its emergence as an important commercial network." "126 But as the Internet began to grow exponentially in the mid 1990s, the FCC's posture of separating "telecommunications services" from "information services" became less and less tenable. ${ }^{127}$ Indeed, dividing the communications world by service category has become obsolete with computer-to-computer communications that can now replicate other categories of services. ${ }^{128}$ Thus, Internet service clearly fell within the FCC's jurisdiction. But it did not square well with the FCC's longstanding framework, based as it was on service categories. The categorical lines evaporated with Internet technologies.

The FCC understandably struggled with whether to apply traditional regulatory frameworks to a technology as dynamic as the Internet. ${ }^{129}$ Even 1996 legislation addressing Internet networks became outdated by the late

121. Regulatory and Policy Problems Presented by the Interdependence of Computer and Communications Services and Facilities, 7 F.C.C.2d 11 (1966); see also Bickerstaff, supra note 119, at 7-13 (recounting the FCC's launch of the Computer I inquiry).

122. Werbach, supra note 40, at 1763.

123. Weinberg, supra note 38, at 213.

124. See id.

125. Weinberg, supra note 38, at 215-18 (juxtaposing Internet technologies with the regulatory framework created by the Communications Act of 1934, which created the FCC).

126. Weiser, supra note 39, at 531 (internal quotation marks omitted).

127. Weinberg, supra note 38, at 212, 232-34; Weiser, supra note 39, at 531; Werbach, supra note 40, at 1764 .

128. Weinberg, supra note 38, at 232-34.

129. Weiser, supra note 39, at 549-50. 
1990s. ${ }^{130}$ Internet scholars rehashed the familiar debate about whether rulemaking or adjudication would be more effective. ${ }^{131}$

Eventually, Internet technologies and business practices matured enough to warrant binding regulation. ${ }^{132}$ But the FCC proceeded initially by making a threat. In 2004, FCC Chairman Michael Powell gave a speech at a popular telecommunications conference, warning the broadband industry that it should preserve net neutrality in various ways, such as allowing broadband users to attach different devices to their networks and use Internet applications of their choice. ${ }^{133}$

This threat turned out to be far from empty. Just one year after Powell's speech, the FCC initiated an investigation against a telephone company that violated one of these principles. ${ }^{134}$ Of course, the FCC did not allege that the company violated Powell's speech. Rather, it cited violations of the Communications Act of $1934 .{ }^{135}$ The FCC backed up its threat.

Moreover, the FCC elaborated on Internet freedoms in a policy statement shortly after the settlement ${ }^{136}$ and promulgated a legally binding rule just six years later, codifying the thrust of Powell's original speech. ${ }^{137}$

Real enforcement was the third (and crucial) part of the FCC's three-part strategy to regulate the Internet. ${ }^{138}$ Adjudication and enforcement require sustained effort. ${ }^{139}$ In comparison, the FDA has brought intermittent

130. Id. at 561 ("By the late 1990s, technological and market conditions had outpaced the premises that underpinned the Telecommunications Act of 1996.").

131. See, e.g., Christopher S. Yoo, Beyond Network Neutrality, 19 HARV. J.L. \& TECH. 1, 67 (2005); Weiser, supra note 39, at 563-64.

132. See Weiser, supra note 39, at 531 (arguing that early non-regulation of the Internet by the FCC was appropriate, but now it is not).

133. Wu, supra note 11, at 1844-45 (citing Michael K. Powell, Chairman, FCC, Preserving Internet Freedom: Guiding Principles for the Industry, Remarks at the Silicon Flatirons Symposium on "The Digital Broadbrand Migration: Toward a Regulatory Regime for the Internet Age" (Feb. 8, 2004), available at http://hraunfoss.fcc.gov/edocs_ public/attachmatch/DOC-243556A1.pdf).

134. See Wu, supra note 11, at 1845 (discussing Madison River Communications, LLC, 20 FCC Rcd. 4295 (2005), available at http://digital.library.unt.edu/ark:/67531/metadc4102/ $\mathrm{m} 1 / 371$.

135. Madison River, 20 FCC Rcd. 4295, 4296 (citing the Communications Act of 1934, 47 U.S.C. \201(b)); Weiser, supra note 39, at 563.

136. Appropriate Framework for Broadband Access to the Internet over Wireline Facilities, Policy Statement, 20 FCC Rcd. 14,986 (Aug. 5, 2005), available at http://digital. library.unt.edu/ark:/67531/metadc4091/m1/708.

137. Wu, supra note 11, at 1852; Preserving the Open Internet, 25 FCC Rcd. 17,905 (Dec. 21, 2010), available at http://digital.library.unt.edu/ark:/67531/metadc39308/m1/451.

138. See Weiser, supra note 39, at 584-89.

139. See id. at 585-86 (noting various deficiencies and underuse of the FCC's Enforcement Bureau and administrative law judges ("ALJs")). 
enforcement actions against software products, ${ }^{140}$ but it has not brought enough high-profile cases to offset its primary reliance on nonbinding (and since withdrawn) guidance.

The FCC deployed threats as a short-term precursor to more traditional, binding regulation; the FDA relied on threats as a long-term crutch. And unlike the FDA, the FCC did not make empty threats. These disparate experiences reveal important limitations on agency threats.

\section{THE REGULATORY TOOLKIT FOR DISRUPTIVE INNOVATIONS}

By its nature, disruptive innovation challenges regulators. U.S. culture values innovation, sometimes for its own sake, and does not want regulation to be technologically regressive. ${ }^{141}$ At the same time, new technologies can disturb existing regulatory frameworks, triggering intense public debates about whether they are compatible with accepted social and legal norms. ${ }^{142}$ Instinctively, most assume that regulating novel technologies requires more information and longer decision-making processes than familiar, established technologies do. ${ }^{143}$

Compounding the challenge, regulators like the FDA and FCC must make four different types of decisions when confronting novel technologies or business practices. The decision to rely on agency "threats" is not only a decision about the form of intervention, but also about the timing of intervention, how durable that intervention should be, and how rigorously

140. For example, the FDA has an online database of warning letters issued to suspected violators. It categorizes these warning letters by subject, with three relating to device software: "Devices/Computer Software," listing only two warning letters (one in 1997 and one in 1998); "Devices/Patient Monitors Software," listing one warning letter from 1999; and "QSR for Medical Devices/Picture Archiving \& Communication Systems Software/Adulterated," listing one warning letter in 2001. FDA's Electronic Reading RoomWarning Letters, FDA, http://www.accessdata.fda.gov/scripts/warningletters/wlFilter BySubject.cfm (last visited Nov. 9, 2013) (follow hyperlinks from subject index to individual subjects). Of course, these database categories may not be comprehensive, and a search through the FDA's warning letter database for "software" generates many more results (although some of these do not concern software devices, but software used for manufacturing or other reasons).

141. See Huber, supra note 10, at 1028.

142. Gaia Bernstein, The Socio-Legal Acceptance of New Technologies: A Close Look at Artificial Insemination, 77 WASH. L. REV. 1035, 1035-36 (2002).

143. Cf. Super, supra note 68, at 1411, 1416-17 (noting that "commentators assume that more information is an unalloyed good" and that "delaying decision making is necessary to allow procedures consistent with careful deliberation or broad participation," while new technologies can "complicate" and "chang[e] the optimal timing of" decision-making). 
the agency should monitor and sanction noncompliance. The regulator thus makes four related types of decisions:

1. Timing: When should the agency intervene, if at all? Does waiting necessarily generate a better informational basis on which to regulate? What are the drawbacks of waiting?

2. Form: Should the agency regulate via rule, adjudication, guidance, or some alternate form? Given the costs and benefits of each, which best accommodates the uncertainties of the innovation? Does form even matter?

3. Durability: Should the agency's intervention be permanent, or temporary, or conditional? How long should it endure? And are there ways to better calibrate regulatory interventions to the innovation?

4. Enforcement: How rigorously should the agency monitor and sanction noncompliance? How much should agencies temper enforcement against novel products, firms, or industries?

With each decision, an agency must prioritize competing claims on these questions by different constituents, including Congress, the President, industry, and regulatory beneficiaries (those who benefit from the regulation of others). ${ }^{144}$

This Part considers how agencies might respond to disruptive innovation along these four dimensions. Informal agency "threats" seem, at first glance, like a nice middle ground-allowing agencies to say something early, but in a malleable and nonbinding way, while preserving maximum flexibility to gather more information. However, this Article questions the emerging sentiment that regulators should use "threats" to maintain a flexible stance, drawing lessons from the FDA's approach to software and the FCC's approach to the Internet. As explained above, the FCC disciplined its threats with timely enforcement and rulemaking. But the FDA's strategy compounded its problems along each dimension: on timing, it was late; on form, it was casual; on durability, it was transient; and on enforcement, it was spotty. These cumulative defects have undermined the FDA's long-term authority over software and raise serious questions about the prevailing orthodoxy on regulating new technologies.

144. Nina A. Mendelson, Regulatory Beneficiaries and Informal Agency Policymaking, 92 CORNELL. L. REV. 397, 401-02 (2007). 


\section{A. TIMING}

For regulators confronting disruptive technologies, timing is paramount. Premature regulation might suffocate new technologies. ${ }^{145}$ Regulating with alacrity risks regulating in error. ${ }^{146}$ Yet, deferring regulation to some future date forgoes the benefits that would accrue to the public while the technology is being regulated. ${ }^{147}$ As the FDA's posture on software reveals, initial reticence to regulate can easily harden into a long-term, laissez faire default. Introductory stances often remain unexamined.

With novel technologies, agencies also risk paralysis by analysis. New technologies often present unforeseen risks if under-regulated ${ }^{148}$ and dramatic opportunity costs if overregulated. ${ }^{149}$ The inclination of most regulators is to avoid both extremes. Thus, the timing calculus is highly variable for new technologies. Agencies understandably agonize over it.

Despite the stakes, legal scholarship is oddly ambivalent about timing. ${ }^{150}$ Administrative law scholars in particular are far more preoccupied with the form regulation takes rather than when agencies take it. But the two, no doubt, are connected. As Jacob Gersen and Eric Posner emphasize, decisions about the timing of laws can be just as important as decisions about their content. ${ }^{151}$

David Super argues convincingly that regulatory decisions are often postponed counterproductively, usually to wait for more information and

145. Wu, supra note 11 , at 1849.

146. Jacob E. Gersen \& Eric A. Posner, Timing Rules and Legal Institutions, 121 HARV. L. REV. 544, 558 (2007). Gervais, in particular, is concerned with regulating in error. Gervais, supra note 11 , at 674 .

147. Gersen \& Posner, supra note 146, at 558.

148. See, e.g., Lars Noah, Assisted Reproductive Technologies and the Pitfalls of Unregulated Biomedical Innovation, 55 FLA. L. REV. 603, 614-24 (2003) (discussing mounting evidence of risks associated with the relatively unregulated field of assisted reproductive technology); Rabin, supra note 35, at 1304-05 (noting that, in the realm of health and safety regulation, "inaccurate, insufficiently protective, administrative decisions might lead to irreversible longterm risks to society of devastating magnitude"); Nicholas Bagley \& Richard L. Revesz, Centralized Oversight of the Regulatory State, 106 COLuM. L. REV. 1260, 1296-1300 (2006) (suggesting reasons why regulators might err on the side of under-regulation).

149. Huber, supra note 10 , at 1027.

150. Super, supra note 68, at 1379 (arguing that scholarship on timing tends to "confound the questions of when a decision should be made with who should make it"). A recent article that does focus sustained attention to timing focuses on legislative timing, giving only passing thought to administrative agencies. See Gersen \& Posner, supra note 146. Gervais addresses the timing of regulation for new technologies, but relies on the axiom that "technological change happens faster than social change" to argue that regulation of new technologies may be premature and fraught with error. Gervais, supra note 11, at 683-84.

151. Gersen \& Posner, supra note 146. 
preserve maximum flexibility. ${ }^{152}$ This observation describes the FDA's posture towards software. Regulatory flexibility and discretion sound good in theory. A flexible stance allows regulators to revisit and retreat to earlier positions if necessary, and tailor their approaches as they learn more. Indeed, American culture generally values flexibility and condemns inflexibility. ${ }^{153}$ Our legal culture valorizes executive discretion. ${ }^{154}$ And legal scholarship in particular embraces regulatory flexibility, usually as a reaction to the ossification of agency rulemaking. ${ }^{155}$

But flexibility often leads to what Super calls "legal procrastination" and a resulting regulatory inertia. ${ }^{156}$ Administrative law scholarship generally assumes that deferring action will necessarily lead agencies to use more robust, deliberative procedures that will generate more fair and accurate rules. ${ }^{157}$ But as the FDA's policy towards software demonstrates, this assumption can be wrong. Flexibility and lengthy deliberation are only worthwhile if they will significantly improve the quality of the agency's decision. ${ }^{158}$ Bureaucratic delay is widely recognized and condemned in American culture, but its costs to regulatory beneficiaries are infrequently studied. ${ }^{159}$

Regulators also tend to overvalue gathering information about new technologies, which further distorts decisions on regulatory timing. The need for information has long been a key concern when addressing new risks. ${ }^{160}$ $\mathrm{Wu}$ channels Freidrich Hayek in arguing that traditional regulation is

152. Super, supra note 68, at 1380, 1409.

153. Id. at 1409 ("In social life, calling someone 'flexible' is generally a compliment; inflexibility is characteristic of bullies, dinosaurs, and control freaks.").

154. Id. at 1409.

155. Id. at 1410 n.148 (citing a string of very recent articles in a range of subjects touting flexibility); Thomas O. McGarity, The Expanded Debate over the Future of the Regulatory State, 63 U. CHI. L. REV. 1463, 1523 (1996).

156. Super, supra note 68 , at 1382.

157. Id. at 1398.

158. Id. at 1406 .

159. One exception is the literature on delaying environmental regulation. See, e.g., LeaRachel D. Kosnik, Sources of Bureaucratic Delay: A Case Study of FERC Dam Relicensing, 22 J.L. ECON. \& ORG. 258 (2005); Hilary Sigman, The Pace of Progress at Superfund Sites: Policy Goals and Interest Group Influence, 44 J.L. \& ECON. 315 (2001); Amy Whritenour Ando, Waiting to be Protected Under the Endangered Species Act: The Political Economy of Regulatory Delay, 42 J.L. \& ECON. 29 (1999).

160. Gervais, supra note 11, at 684-87 (addressing the "unintended consequences" that generate from early regulatory intervention, even questioning the efficacy of regulatory requirements like car seatbelts). But see Huber, supra note 10, at 1051-52 (acknowledging the concern, but questioning its salience). 
"impressive in a world of perfect information, but terrible in this world."161 However, for regulators, perfect information is often the enemy of good information. ${ }^{162}$ Culturally, we are situated firmly in the Information Age, and thus tend to overvalue information. ${ }^{163} \mathrm{We}$ obsess about gathering all available information and recoil from making any big decisions without it. ${ }^{164}$ Legal culture in particular values information over other inputs into legal decisions, such as the capacity to implement and enforce laws. ${ }^{165}$ And the penetration of economics into legal thought, particularly the well-known market failure of information asymmetries, further aggravates this overemphasis on gathering information. ${ }^{166}$

But more information does not necessarily equate to better information. Ironically, the more information we gather, the more effort it takes to make a decision based on it. ${ }^{167}$ Nor does information itself necessarily make agencies more efficient long-term. The more the FDA learned about device software, the more overwhelmed it became. Indeed, the FDA explained that it withdrew its 1989 Draft Software Policy because of the volume, variety, and complexity of medical device software. ${ }^{168}$ In fact, waiting for better information can be counterproductive. Agency flexibility can be overrated. ${ }^{169}$ Too much of it can paralyze agencies, ${ }^{170}$ a notion that might offend our intuitions about how government should work.

Equally important, early interventions can benefit both regulated industry and regulatory beneficiaries. As Super demonstrates, "[d]ecisions rarely become more valuable to society as a whole when rendered later." regulated parties may appreciate the added certainty and reduced cost of compliance with early regulatory decisions. ${ }^{172}$ The conventional wisdom that

161. Wu, supra note 11, at 1849 (citing F.A. Hayek, The Use of Knowledge in Society, 35 AM. ECON. REV. 519, 519 (1945)).

162. Super, supra note 68, at 1380.

163. Id. at 1379.

164. Id. at $1409-10$.

165. Id. at 1401 ("We avoid discussing deficiencies in decisional or enforcement capacity as they embarrass the law ....").

166. Id. at 1401-02.

167. Id. (citing Barry SChWARTZ, The Paradox of Choice: Why More is Less 23 (2004) (noting that information overload can paralyze decision making)).

168. 2011 Mobile Medical Applications Draft, supra note 97, at 5.

169. Super, supra note 68, at 1381 (using as case studies the Federal Emergency Management Agency's response to Hurricane Katrina in 2005).

170. Id. at 1381.

171. Id. at 1405 .

172. Id. 
regulation necessarily stifles innovation does not always hold. ${ }^{173}$ Indeed, an industry coalition of app developers and device makers opposed an effort in Congress to prohibit the FDA from finalizing a draft guidance on mobile software for eighteen months. ${ }^{174}$ Industry can benefit from early, clear regulation.

The obvious exceptions are when the early regulatory intervention is deeply flawed, or when no intervention is needed, either because the problem is not severe enough or because it occurs with low frequency. ${ }^{175}$ But from the agency's perspective, early decisions can capitalize on a motivated regulator's early passion for and attention to the issue, ${ }^{176}$ which may wane over time absent an external shock. Typically, the shock is some tragedy followed by Congressional intervention forcing the agency to respond. ${ }^{177}$ And such reactionary regulation is likely to be more severe and potentially miscalibrated. ${ }^{178}$

Early interventions may also benefit from a more objective regulatory atmosphere, before parties become entrenched and adversarial. In contrast, deferring action (usually in the name of preserving discretion and gathering information), often leads to incremental decision making, which is more susceptible to interest group influence. ${ }^{179}$ Agencies that precommit to policies earlier can better avoid bias and capture, emulating (very crudely) a Rawlsian "veil of ignorance." 180 Although regulated firms generally prefer certainty,

173. This sentiment was echoed during a recent public workshop on FDA regulation of the latest generation of device software. FDA Public Workshop, supra note 80 (statement of Dean Kross, M.D.) (citing a decade of experience with unregulated electronic health records (EHRs) and prescribing software, which produced "ancient, hostile" applications with very little transparency as to how they operate). Gervais seems particularly wedded to the idea that there is an inverse correlation between regulation and beneficial innovation. Gervais, supra note 11, at 668-69. 82.

174. Letter from mHealth Regulatory Coalition to Senators Enzi and Harkin, supra note

175. Super, supra note 68, at 1405-06 (citing Louis Kaplow, An Economic Analysis of Legal Transitions, 99 HARV. L. REV. 509, 593 (1986) (favoring ex post rather than ex ante resolution with low frequency problems)).

176. Gersen \& Posner, supra note 150, at 566.

177. Efthimios Parasidis, Patients over Politics: Addressing Legislative Failure in the Regulation of Medical Products, 2011 WISC. L. REV. 929, 937-49 (2011) (detailing the history of congressional reactions granting FDA more authority over drugs in the wake of tragedies).

178. See Super, supra note 68, at 1451.

179. Colin S. Diver, Policymaking Paradigms in Administrative Law, 95 HARV. L. REv. 393, 424-25 (1981) (noting that incremental policymaking is susceptible to interest groups and can sacrifice the agency's objectivity); Super, supra note 68, at 1418-19.

180. Gersen \& Posner, supra note 146, at 572-73; Super, supra note 68, at 1378 (citing JOHN RAWls, A THEORY OF JUSTICE 136-37 (1971)). A "veil of ignorance" generally "suppresses self-interested behavior on the part of decisionmakers ... by subjecting the 
and thus should prefer definite rules, current efforts tend to be aimed primarily at weakening agency oversight. ${ }^{181}$ Delay may invite obstruction.

Of course, early intervention imposes costs on industry-costs that may be too heavy for fledgling industries to bear. And regulators should be aware of legal "transitions" that upset settled expectations. ${ }^{182}$ The government should remain sensitive (as it has been under the Obama administration) ${ }^{183}$ to imposing new costs on firms.

That said, recent experience with other new technologies illustrates the consequences of unregulated medical innovation. ${ }^{184}$ For example, assisted reproductive technologies ("ART") like artificial embryo implantation proliferated in the 1980s and 1990s without any real FDA oversight, and despite the lack of clinical evidence that these interventions were safe and effective. ${ }^{185}$ In the meantime, unproven reproductive technologies gave rise to a significant industry, and "questions quickly arose about the accuracy of promotional claims."186 Arguably, neither tort law, state oversight, nor professional self-regulation filled in. ${ }^{187}$ A similar story describes the explosive growth of the dietary supplement industry, which also advanced with very

decisionmakers to uncertainty about the distribution of benefits and burdens that will result from the decision." Adrian Vermeule, Veil of Ignorance Rules in Constitutional Law, 111 YALE L.J. 399, 399 (2001).

181. Super, supra note 68, at 1428.

182. Barbara H. Fried, Ex Ante/Ex Post, 13 J. Contemp. Legal Issues 128 (2003); Huber, supra note 10, at 1064 (noting that "transition costs are largely absent when new products are regulated"); Kaplow, supra note 175.

183. See, e.g., Exec. Order No. 13,563, Improving Regulation and Regulatory Review, 76 Fed. Reg. 3821, 3822 (Jan. 21, 2011) (calling for federal agencies to identify ways to achieve regulatory goals "that are designed to promote innovation," promote regulatory flexibility, and reduce unnecessary regulatory burdens).

184. See, e.g., Noah, supra note 148.

185. See id.

186. Id. at 614 .

187. Id. at 648. Eventually, the FDA asserted jurisdiction over some ART technologies by proposing rules, and sent warning letters with notices of violations. See Current Good Tissue Practice for Manufacturers of Human Cellular and Tissue-Based Products, 66 Fed. Reg. 1508 (2001); Establishment Registration and Listing for Manufacturers of Human Cellular and Tissue-Based Products, 63 Fed. Reg. 26,744 (1998); Noah, supra note 148, at 650-51. It is also contested whether tort law and self-regulation by the American Society for Reproductive Medicine ("ASRM") did indeed fill the regulatory void. See, e.g., Kimberly M. Mutcherson, Welcome to the Wild West: Protecting Access to Cross Border Fertility Care in the United States, 22 Cornell J.L. \& PUB. POL'Y 349, 361-62 (2012) (discussing the United States' "not completely deserved reputation as the Wild West of fertility treatment"). 
little meaningful oversight ${ }^{188}$ and with very little evidence to support its claims. ${ }^{189}$ As noted, waiting does not necessarily generate superior regulation.

\section{B. FORM}

A parallel decision for regulators confronting new technologies is form. Agencies are unique among government institutions in having several choices of policymaking form. ${ }^{190}$ For years, scholars have debated whether agencies should make policy ex ante via rulemaking or ex post via adjudication. ${ }^{191}$ The debate used to weigh these two primary modes, until rulemaking began to predominate in the 1970s. ${ }^{192}$ By the early 1990s, the debate had shifted to rulemaking versus guidance, just as agencies began to rely on guidances even more than rules. ${ }^{193}$

Like most agencies, the FDA is statutorily authorized to choose among these forms. ${ }^{194}$ Agencies enjoy significant discretion, as this choice is virtually immune from judicial review. ${ }^{195}$ This Section evaluates the three primary forms of policymaking (rulemaking, adjudication, and guidance), as well as newer forms, and whether these forms matter when confronting new

188. The lack of oversight of dietary supplements was not due to the FDA dragging its feet, but to Congress tying the FDA's hands. See Symposium: The Dietary Supplement Health and Education Act: Regulation at a Crossroads, 31 AM. J.L. \& MED. 147-364 (2005) (providing a comprehensive overview of how Congress prevented FDA action).

189. There have been many takedowns of the dietary supplement industry. For a recent survey of evidence (especially the lack thereof), see PAUL A. OFFIT, DO YOU BELIEVE IN Magic? The Sense And Nonsense of Alternative Medicine (2013) (finding that only four of the 51,000 supplements on the U.S. market are supported by valid scientific evidence).

190. Magill, supra note 55.

191. See, e.g., Louis Kaplow, Rules Versus Standards: An Economic Analysis, 42 DUKE L.J. 557, 562-63 (1992) (wrestling with whether decision making via enforcement and adjudication are more efficient than rulemaking ex ante); Magill, supra note 55, at 1403 n.69 (citing two decades of literature on the subject); Super, supra note 68, at 1411-12.

192. Magill, supra note 55, at 1398-99 (noting that after Congress passed the APA in 1946, most agencies carried out their statutory obligations by adjudication in the 1950s and 1960s, shifting decidedly towards broad-based rulemaking in the 1970s).

193. Mendelson, supra note 144, at 398 (noting that the volume of guidances is "massive" compared to rules). Aware of this trend and suspicious of abuse, the House Committee on Oversight and Government Reform held hearings and issued a report in 2000. See H.R. REP. NO. 106-1009 (2000). In response, the EPA revealed that it had issued over 2000 guidances between 1996 and 1999, and OSHA revealed over 3,000 during the same period. In comparison, the EPA issued only 100 "significant" rules and OSHA twenty during that same period. Mendelson, supra note 144, at 399.

194. Magill, supra note 55, at 1388 n.11 (citing, for example, 21 U.S.C. SS 334, 371(a) (2000)).

195. Id. at 1405-42 (discussing the germinal case, SEC v. Chenery Corp., 332 U.S. 194 (1947)). 
technologies. I argue that, in retrospect, the FDA's reliance on guidance weakened its oversight of software, and that it now risks repeating its mistake with the next generation of software.

\section{Rulemaking}

The FDA could have proceeded by rule. The benefits of rules are many, ${ }^{196}$ although enthusiasm for them long ago waned. Rules can set clear, authoritative, and durable requirements. The rulemaking process uses robust, transparent procedures that accommodate broad public participation. ${ }^{197}$ The rulemaking process is designed to ventilate issues of broad public concern and is particularly suitable when the problem is widespread and foreseeable. ${ }^{198}$ As such, rulemaking can be more efficient than making policy via individualized adjudication, as federal agencies discovered in the 1960s and 1970s. ${ }^{199}$ Rules are widely published and are more easily accessible than adjudications, although this advantage is slighter in an era of agency websites. ${ }^{200}$ Rules are also subject to more oversight by politically accountable institutions, like Congress and the President. But above all, rules bind. Agencies can enforce them. This was the chief limitation of the FDA's reliance on guidance.

Of course, the disadvantages of rulemaking are also abundant, as well canvassed by scholars. The most familiar is that promulgating rules requires a long, lumbering process ${ }^{201}$ —one that is almost universally condemned as being ossified and prolonged by cumulative procedural burdens, ${ }^{202}$ including executive review and various statutory hurdles. ${ }^{203}$ Studies confirm this

196. See generally Arthur Earl Bonfield, State Administrative Policy Formulation and the Choice of Lawmaking Methodology, 42 ADMIN. L. REV. 121, 122-36 (1990) (discussing the benefits of rulemaking vis-à-vis adjudication).

197. Rulemaking by federal agencies is governed by $\int 553$ of the Administrative Procedure Act (APA), 5 U.S.C. $\int 553$ (2012).

198. NLRB v. Bell Aerospace Co., 416 U.S. 267, 292-94 (1974) (discussing when a legislative rule would be appropriate in reviewing agency choices for an abuse of discretion); cf. Magill, supra note 55, at 1408 .

199. Antonin Scalia, Vermont Yankee: The APA, the D.C. Circuit, and the Supreme Court, 1978 Sup. CT. REV. 345, 376 (1978).

200. Cortez, Adverse Publicity by Administrative Agencies in the Internet Era, supra note 60, at 1374.

201. See 5 U.S.C. $\int 553$.

202. Magill, supra note 55, at 1390-91, $1391 \mathrm{n} .17$ (citing the "large literature on the 'ossification' of the rulemaking process”). Mark Seidenfeld once counted 109 discrete rulemaking requirements. Mark Seidenfeld, A Table of Requirements for Federal Administrative Rulemaking, 27 FLA. ST. U. L. REV. 533 (2000).

203. There are well-known executive burdens that apply to most rulemaking, the most recognized being review by the Office of Information and Regulatory Affairs ("OIRA") in the Office of Management and Budget (“OMB”). See, e.g., Exec. Order No. 12,291, Federal 
critique, finding that rulemaking at some agencies can take upwards of two years to complete. ${ }^{204}$ At the Department of Health and Human Services ("HHS"), for example, the average duration of rulemaking without a statutorily imposed deadline was a staggering 817 days. ${ }^{205}$

Rules are also critiqued for being inflexible. They are hard to update, as doing so requires another round of notice and comment. ${ }^{206}$ Rules also can be overinclusive or underinclusive, and thus unjust. ${ }^{207}$ And like statutes, rules are prospective, so they must be general enough to accommodate unforeseen conduct. $^{208}$ These factors undoubtedly weigh on agency decisions to forgo rulemaking.

\section{Adjudication}

The FDA also could have established policy via adjudication, which has its own pros and cons. Among the pros, adjudication allows agencies to address problems in discrete, concrete circumstances, rather than prospectively and abstractly, as with rulemaking. ${ }^{209}$ Agencies can use

Regulation, 3 C.F.R. 127 (1982); Exec. Order No. 12,866, Regulatory Planning and Review, 3 C.F.R. 638, 638, 642, 644 (1994) (\$ 4 "Planning Mechanism" and \ 6 "Centralized Review of Regulations"). And as many authors observe, there are lesser-known rulemaking requirements imposed by statute. Erica Seiguer \& John J. Smith, Perception and Process at the Food and Drug Administration: Obligations and Trade-Offs in Rules and Guidances, 60 FOOD \& DRUG L.J. 17, 19 (2005) ("In addition to the APA, there are a number of laws that impact the development of rules .... [A] variety of Executive Orders . . also apply."); Connor N. Raso, Note, Strategic or Sincere? Analyzing Agency Use of Guidance Documents, 119 YALE L.J. 782, 788, 788 n.16 (2010) (“Agencies must also complete a number of lesser-known procedural requirements before issuing a legislative rule.”); e.g., Unfunded Mandates Reform Act of 1995, 2 U.S.C. \S 1501-71, 1532-35 (2012); Small Business Regulatory Enforcement Fairness Act of 1996, Pub. L. No. 104-121, 110 Stat. 857 (codified as amended in scattered sections of 5 U.S.C. and 15 U.S.C.); Regulatory Flexibility Act, 5 U.S.C. SS 601-612 (2012);

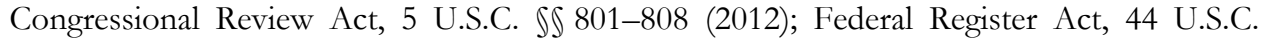
\1505 (2012); Paperwork Reduction Act of 1995, 44 U.S.C. \\ 3501-3549 (2012); Small Business Paperwork Relief Act of 2002, 44 U.S.C. SS 3504(c), $3506(\mathrm{i}), 3520$ (2012).

204. Jacob E. Gersen \& Anne Joseph O'Connell, Deadlines in Administrative Law, 156 U. PA. L. REV. 923, 988 tbl.12 (2008) (studying the period between 1988 and 2003, and noting rulemaking actions without congressionally imposed deadlines).

205. Id.

206. See Mendelson, supra note 144, at 410.

207. Mark Seidenfeld, Bending the Rules: Flexible Regulation and Constraints on Agency Discretion, 51 Admin. L. REV. 429, 440-41 (1999); Richard B. Stewart, Administrative Law in the Twenty-First Century, 78 N.Y.U. L. REV. 437, 446 (2003) (noting that centralized, command-and-control regulation "suffers from the inherent problems involved in attempting to dictate the conduct of millions of actors in a quickly changing and very complex economy and society throughout a large and diverse nation."'); see also Mendelson, supra note 144, at 438.

208. Mendelson, supra note 144 , at 410.

209. Bonfield, supra note 196, at 122-36. 
adjudication to respond quickly to problematic conduct as it arises. ${ }^{210}$ Adjudication also allows agencies to create policy incrementally, in the absence of consensus. ${ }^{211}$ Another benefit is that agencies can also target egregious, outlier conduct that does not occur often enough to require broad-based rulemaking. ${ }^{212}$ And if the conduct of individual firms differs in key ways, adjudication can account for that. ${ }^{213}$

But like rulemaking, adjudication has well-known deficiencies. Adjudication does not invite broad public participation, so it can be awkward for establishing broader policies. ${ }^{214}$ Agencies can choose sympathetic targets for adjudication, whose conduct may not fairly represent industry practices. ${ }^{215}$ Any precedents established in adjudication can be limited by facts peculiar to the case. ${ }^{216}$ Moreover, precedents technically bind only the parties. ${ }^{217}$ Thus, agencies pushing new legal theories or interpretations face problems with fair notice, and may find it difficult to enforce the new position. ${ }^{218}$ Formal administrative adjudications resemble judicial trials, with all their inefficiencies. ${ }^{219}$ And agencies wishing to enforce their adjudications in court must convince the Department of Justice to take up their cause. ${ }^{220}$ Adjudication may also be inefficient vis-à-vis rulemaking when the agency has to relitigate the issue repeatedly.

Yet the familiar dichotomy between rulemaking and adjudication can be a false one. The two must coexist if agencies wish to enforce rules and clarify them in individualized applications. ${ }^{221}$ Rules can be toothless without enforcement, and enforcement requires something to enforce. Guidances can depart from this symbiosis.

\section{Guidances}

When the FDA first announced a software policy in 1987, it chose to make policy via guidance - a pattern it continues today. For agencies, the major attraction of guidances is that guidances need not comply with the

210. Magill, supra note 55, at 1396-97.

211. Id.

212. Id.

213. Id. at $1444-45$.

214. Magill, supra note 55, at 1396.

215. Id.

216. Id.

217. Id.

218. Mendelson, supra note 144 , at 436.

219. 5 U.S.C. $\iint 556-557$ (2012) (including the APA's procedures for formal adjudication and rulemaking); Magill, supra note 55, at 1391.

220. Magill, supra note 55, at 1391, 1393.

221. Bonfield, supra note 196, at 122-36. 
notice-and-comment rulemaking procedures required by the $\mathrm{APA}^{222}$ or any other statute. ${ }^{223}$ Publishing guidances is quicker than even most forms of adjudication. ${ }^{224}$ Compared to rulemaking, guidances are a very economical way to signal agency preferences. ${ }^{225}$ They give agencies greater flexibility to update or retreat from the policy when necessary. ${ }^{226}$ Guidances are useful for coordinating lower level agency personnel. ${ }^{227}$ Agencies may also prefer guidances because they are virtually immune from pre-enforcement judicial review and are subject to less congressional oversight. ${ }^{228}$ Finally, guidances are generally credible, ${ }^{229}$ and they can be "sticky" like regulations. ${ }^{230}$

Agencies are known to use guidances to clarify highly technical or scientific requirements that would be difficult to update via rulemaking or

222. 5 U.S.C. $\int 553$ (2012). In the early 1980s, Congress considered bills that would have required agencies to use notice-and-comment procedures for many guidances, but none of these bills passed. See H.R. 2327, 98th Cong. (1983); H.R. 220, 98th Cong. (1983); S. 1080, 97th Cong. (1982); H.R. 746, 97th Cong. (1981); Mendelson, supra note 144, at 401 \& n.25.

223. Note, however, that even the guidance document process is becoming burdened by procedure. In 2007, the Bush administration published Executive Order 13,422, which allows the $\mathrm{OMB}$ to require agencies to consult with it before issuing a "significant" guidance document, defined as one that has an economic impact of more than $\$ 100$ million in any single year, or raises important legal issues (among other criteria). Exec. Order No. 13,422, 3 C.F.R. 191-92 (2007) (rescinded by President Obama's Exec. Order. No. 13,497, 3 C.F.R. 218 (2013)).

224. See Magill, supra note 55, at 1391-92 (describing developing guidances as "relatively cheap【" for agencies in comparison to adjudication and formal rulemaking).

225. Michael Asimow, Nonlegislative Rulemaking and Regulatory Reform, 1985 DUKE L.J. 381, 404-08 (1985) (arguing that agencies rely on guidance documents when budgetary pressures require it); Mendelson, supra note 144, at 408. In the words of one FDA official, "In an ideal world, we would always do rulemaking, but it is not as responsive and there is a lot of process involved, not only internal to the agency, but outside FDA." Seiguer \& Smith, supra note 203 , at 24 . Another FDA official said, "To do a rule, it's a huge ordeal ... there are economic analyses of the impact, notice and comment, involvement of the OMB, etc." Id.; see also Gersen \& Posner, supra note 59, at 588-89, 594-95 (describing the similar allure of soft law statutes by Congress).

226. Mendelson, supra note 144, at 408.

227. Peter L. Strauss, Publication Rules in the Rulemaking Spectrum: Assuring Proper Respect for an Essential Element, 53 ADMIN. L. REV. 803, 808 (2001).

228. Magill, supra note 55, at 1395; Mendelson, supra note 144, at 408.

229. See Gersen \& Posner, supra note 59, at 589 (noting that soft law can be credible even when it is not costly to speak).

230. The rulemaking process has been criticized as being inefficient and "sticky." See, e.g., Jody Freeman, Collaborative Governance in the Administrative State, 45 U.C.L.A. L. REV. 1, 3 (1997); Jason M. Solomon, Law and Governance in the 21st Century Regulatory State, 86 TEX. L. REV. 819, 822 (2008) (book review) (discussing the "stickiness of the rulemaking process"). But stickiness may be good, if the agency wants the guidance to endure. 
adjudication. ${ }^{231}$ These issues may require "a scalpel, not a sledgehammer."232 Indeed, there is almost a consensus in the literature that guidances are more appropriate than rulemaking to address rapid technological and scientific advancement, as Wu argues. ${ }^{233}$ In a recent study, representatives from both the FDA and regulated industry agreed on this use of guidances. ${ }^{234}$

But for all the glowing evaluations, relying on guidance does pose problems. Many scholars suspect that agencies abuse guidance as a way to skirt procedure, ${ }^{235}$ though a recent study disputes this. ${ }^{236}$ Agency consideration may not be disciplined the same way as when subject to the procedures governing rulemaking and adjudication ${ }^{237}$-although in FDA's case its consideration is tempered by its Good Guidance Practices, and for most agencies by executive review protocols. ${ }^{238}$ Guidances are hailed for their flexibility, yet one study found that they are updated with even less frequency than rules. ${ }^{239}$ And if agencies use guidances to address scientific and technical issues, they might be doing so at the expense of public input.

The major shortcoming is that guidance is not enforceable. Agencies cannot allege violations of guidance documents or initiate enforcement actions based solely on them. ${ }^{240}$ Defenders of guidance tend to emphasize its

231. Lisa Schultz Bressman, Beyond Accountability: Arbitrariness and Legitimacy in the Administrative State, 78 N.Y.U. L. REV. 461, 545-56 (2003); Raso, supra note 203, at 815 (citing as examples the Department of Transportation, EPA, and OSHA).

232. Philip J. Weiser, The Next Frontier for Network. Neutrality, 60 ADMIN. L. REV. 273, 277 (2008).

233. See Wu, supra note 11 , at 1842, 1848-54.

234. See, e.g., Seiguer \& Smith, supra note 203, at 23. Seiguer and Smith interviewed several representatives from the FDA and industry, and found that " $[t]$ hose interviewed agreed that due to the rapid pace of scientific advancement, guidances . . . provide the best means of providing information to assist industry in understanding and complying with regulatory requirements." In fact, they noted that a common theme among interviewees was "[t] he importance of guidances in an era of complex science." Id.

235. Raso, supra note 203, at 785-87.

236. Id. at 809-23 (reviewing five agencies (EPA, FCC, FDA, IRS, and OSHA) over ten years (1996-2006) and finding that agencies generally do not use guidance documents to avoid rulemaking, at least for "significant" policies). Jacob Gersen and Eric Posner discuss some of the same "rule of law" objections to soft law by Congress. Gersen \& Posner, supra note 59, at 597-98. Others have proposed procedural reforms to legitimate guidances. See, e.g., Jessica Mantel, Procedural Safeguards for Agency Guidance: A Source of Legitimacy for the Administrative State, 61 ADMIN. L. REV. 343 (2009).

237. Magill, supra note 55, at 1397, 1446.

238. See 21 U.S.C. \371(h) (2012); FDA Good Guidance Practices, 21 C.F.R. \ 10.115 (2013).

239. Raso, supra note 203, at 818-19 (noting, however, the limitations of the available data).

240. William Funk, When is a "Rule" a Regulation? Marking a Clear Line Between Nonlegislative Rules and Legislative Rules, 54 ADMIN. L. REV. 659, 661-62 (2002); Magill, supra note 55, at 
benefits to industry without contemplating how it can disadvantage regulatory beneficiaries. ${ }^{241}$ Even an open, transparent guidance process like the FDA's can skew heavily towards industry, per Nina Mendelson's critique that agencies generally solicit comments on guidance from industry, but not from regulatory beneficiaries. ${ }^{242}$

Notwithstanding these criticisms, most scholars agree that some guidance is better than none. ${ }^{243}$ But it is far from clear that doing nothing is the only counterfactual, or that guidance is always preferable to rulemaking, particularly when enforcement matters. ${ }^{244}$ Agencies like the FDA still choose to promulgate rules when they desire enforceability. ${ }^{245}$

In many ways, the FDA's reliance on guidance is notable. The FDA is a serial user, dating back to 1902 , when its precursor first used them. ${ }^{246}$ Today, the FDA issues roughly twice as many guidances as it does rules, ${ }^{247}$ and the ratio has increased steadily since the 1970 s. ${ }^{248}$ By the 1990s, the FDA was generating proportionally fewer regulations and more guidances, such that guidances became the agency's primary mode of policymaking. ${ }^{249}$ By the late

1394; Mendelson, supra note 144, at 406-07, 410. Indeed, courts have prohibited agencies from trying to bind regulated firms via guidance documents. See, e.g., Appalachian Power Co. v. EPA, 208 F.3d 1015 (D.C. Cir. 2000); McLouth Steel Prods. Corp. v. Thomas, 838 F.2d 1317 (D.C. Cir. 1988); Am. Hosp. Ass'n v. Bowen, 834 F.2d 1037, 1045 (D.C. Cir. 1987); Cmty. Nutrition Inst. v. Young, 818 F.2d 943 (D.C. Cir. 1987).

241. See generally Mendelson, supra note 144, at 402, 413-14 (noting that commentators tend to defend guidances by arguing that they are better than nothing at signaling regulators' intent and help keep the conduct of agencies' employees consistent).

242. Id. at 427-29 (noting the general tendency of agencies to "float" draft guidances to industry contacts and solicit comments from them but not the public, and describing the FAA's quite disturbing practice of accepting comments on guidance documents only from a list of seventeen industry organizations, which does not include passenger or consumer safety groups).

243. See, e.g., Michael Asimow, Guidance Documents in the States: Toward a Safe Harbor, 54 ADMIN. L. REV. 631, 647 (2002); Asimow, supra note 225, at 381; Mendelson, supra note 144, at 413.

244. Seiguer \& Smith, supra note 203 , at 28.

245. Id.

246. K.M. Lewis, Informal Guidance and the FD A, 66 FOOD \& DRUG L.J. 507, 509 (2011).

247. Seiguer \& Smith, supra note 203, at 25-26 (finding that during 2001, 2002, and most of 2003, the FDA issued well more than twice as many guidances (298) as rules (129)).

248. Todd D. Rakoff, The Choice Between Formal and Informal Modes of Administrative Regulation, 52 ADMIN. L. REV. 159, 168 (2000) (noting the marked increase in the ratio of guidance documents to rules from the 1970s through the 1990s).

249. Lewis, supra note 246, at 520. In fact, the FDA center responsible for regulating medical devices, the Center for Devices and Radiological Health ("CDRH"), has relied far more on guidances than other centers in the agency. Between 1975 and 2009, CDRH published 659 guidances, compared to 507 by the drug center ("CDER"), 294 by the biologics center ("CBER"), and 190 by the food center ("CFSCAN"). Id. at 549-50 fig.5. 
1990s, observers were already wondering whether rulemaking at the FDA had become an artifact from earlier ages. ${ }^{250}$

The FDA is also notable for being the only agency whose guidance practices are governed by statute and regulation. ${ }^{251}$ The FDA initially proposed its own "Good Guidance Practices" by regulation in 1992. ${ }^{252}$ Congress then codified the regulation by statute in $1997 .{ }^{253}$ Together the two documents require the FDA to solicit public input and use notice-andcomment-like procedures when creating guidances. ${ }^{254}$ Importantly, the statute requires that FDA staff generally follow the agency's own guidances. ${ }^{255}$

Yet, at the end of the day, even FDA guidances cannot bind as a matter of law $^{256}$ (though some report that individual FDA staff sometimes say otherwise). ${ }^{257}$ When push comes to shove in court, the FDA must point to statutes and regulations, not guidance. Any paths blazed via guidance remain legally quarantined until the agency takes action to "codify" them.

\section{New Forms?}

We are undoubtedly in a new era of policymaking pluralism, so the menu for agencies like the FDA is more varied. The traditional substrata of rulemaking, adjudication, and guidance now support variations like negotiated rulemaking, waiver systems, and other more flexible, collaborative forms that are often called regulatory "experimentalism" or "new governance." ${ }^{258}$ Agencies that struggle with limited, stagnant resources are

250. John C. Carey, Is Rulemaking Old Medicine at the FDA?, in FOOD AND DRUG LAw: An Electronic Book of Student Papers 3-6 (Peter Barton Hutt ed., 2012), http:// www.law.harvard.edu/faculty/hutt/book_index.html (last updated Jan. 10, 2013).

251. See 21 U.S.C. \371(h) (2012); FDA Good Guidance Practices, 21 C.F.R. \10.115 (2013).

252. 57 Fed. Reg. 47,314 (Oct. 15, 1992). The FDA finalized its Good Guidance Practices in 1997. 62 Fed. Reg. 8961 (Feb. 27, 1997).

253. Food and Drug Administration Modernization Act, Pub. L. No. 105-115 \ 405, 111 Stat. 2296, 2368-69 (codified at 21 U.S.C. \371(h)); see also Lars Noah, FDA's New Policy on Guidelines: Having Your Cake and Eating it Too, 47 CATH. U. L. REV. 113 (1997) (discussing the FDA's good guidance practices).

254. 21 U.S.C. \371(h); 21 C.F.R. \10.115; see also 65 Fed. Reg. 56,468, 56,473 (Sept. 19, 2000) (addressing public concerns regarding the respective roles of guidances versus noticeand-comment rulemaking); $i d$. at 56,477-78 (describing comment procedures under 21 C.F.R. $\int 10.115$ resembling the notice-and-comment procedures involved in rulemaking under the APA). Some doubt that public comments on guidance documents mean much to the FDA. Seiguer and Smith, supra note 203, at 30.

255. 21 U.S.C. $\int 371(\mathrm{~h})$.

256. 21 U.S.C. $\iint 371(\mathrm{~h})(1)(\mathrm{A}),(\mathrm{h})(2)$.

257. Seiguer \& Smith, supra note 203 , at 30.

258. Michael C. Dorf \& Charles F. Sabel, A Constitution of Democratic Experimentalism, 98 Colum. L. REV. 267 (1998); Freeman, supra note 230; Magill, supra note 55, at 1398-99; 
increasingly looking to alternatives. ${ }^{259}$ The recent scholarly trend is to champion nimble agencies that practice regulatory experimentalism in response to changing circumstances. ${ }^{260}$ Even the hoary FDA drug approval process promises to benefit from experimentalism, argue proponents of new governance like Charles Sabel and Bill Simon. ${ }^{261}$

Although the FDA did not explicitly choose an experimental method with software, one cannot help but sense from the agency a collaborative mood in some of its public hearings (during which FDA comments were more than solicitous of industry and, somewhat asymmetrically, the industry was not shy about voicing displeasure with the FDA's approach). ${ }^{262}$ This highlights how regulatory experimentalism can take for granted the "adversarial legalism" of our regulatory system-our tendency to formally contest policymaking. ${ }^{263}$ Regardless of the form policymaking takes, industry will find ways to contest it.

\section{Does Form Matter?}

It is possible that the differences among policymaking forms are overstated. For example, as Nina Mendelson notes, guidances frequently

David Zaring, Best Practices, 81 N.Y.U. L. REV. 294 (2006). Sabel and Simon, in fact, point to quality regulation of food manufacturing as a paragon of regulatory experimentalism. Charles F. Sabel \& William H. Simon, Minimalism and Experimentalism in the Administrative State, 100 GEO. L.J. 53, 55, 78 (2011). The Food Safety and Modernization Act of 2010 requires the FDA to require processors to use a flexible, customizable cycle of hazard detection and corrective and preventative actions. The process is familiarly known in FDA circles as Hazard Analysis and Critical Control Points ("HACCP"), but was relabeled in the 2010 legislation as Hazard Analysis and Preventive Controls. FDA Food Safety Modernization Act of 2010, Pub. L. No. 111-353, IS 103, 201, 307, 124 Stat. 3885, 3889-90, 3923, 3962 (codified in scattered sections of 21 U.S.C.).

259. See Weiser, The Future of Internet Regulation, supra note 39, at 557 n.106 (quoting former FTC Chairman Robert Pitofsky).

260. See, e.g., Sabel \& Simon, supra note 258, at 56, 78 ("Experimentalism takes its name from John Dewey's political philosophy, which aims to precisely accommodate the continuous change and variation that we see as the most pervasive challenge of current public problems.").

261. Id. at 87-88 (discussing variations on the binary approve/reject decision for FDA reviewers of new drug approvals ("NDAs")).

262. See FDA Public Workshop, supra note 80 (containing transcripts and webcasts of the proceedings).

263. See Solomon, supra note 230, at 821, 847-51 (reviewing two examples of how scholars are rethinking the U.S. regulatory state and concluding that both pay inadequate attention to the "adversarial legalism" described by Robert Kagan). See generally ROBERT A. Kagan, Adversarial Legalism: The American WAy of LAW (2001). Interestingly, moving beyond adversarial legalism would probably require agencies to have more discretion, more finality, and less legal friction. Solomon, supra note 230, at 848. 
resemble rules, which is why they are often called "nonlegislative rules."264 Indeed, courts review whether agencies treat nonlegislative rules as having the force of law. ${ }^{265}$ Scholars have long recognized that finding meaningful doctrinal distinctions between legislative and nonlegislative rules is a task "enshrouded in considerable smog." 266

Moreover, regulated parties may not appreciate the limited legal status of guidances, ${ }^{267}$ as they generally comply with them anyway. ${ }^{268}$ Most observers note that industries choose to treat guidances as binding for practical purposes, ${ }^{269}$ even after Congress pressured agencies to more clearly label their guidances as such and disclaim any legally binding effect. ${ }^{270}$ The FTC even declares (in the Code of Federal Regulations, no less) that it may initiate enforcement actions against parties that do not comply with its guidances. ${ }^{271}$

264. Mendelson, supra note 144 , at 399.

265. See, e.g., Am. Mining Cong. v. Mine Safety \& Health Admin., 995 F.2d 1106, 1109 (D.C. Cir. 1993).

266. David L. Franklin, Legislative Rules, Nonlegislative Rules, and the Perils of the Short Cut, 120 YALE L.J. 276, 286-87 (2010) (citing both courts and scholars that have struggled with the distinction).

267. In fairness to regulated industry, the legal status of FDA guidance documents has always been confusing. For example, in 1977, the FDA promulgated a regulation binding itself with officially published advisory opinions and guidelines. 42 Fed. Reg. 4680, 4708-10 (1977). Although this stance was ostensibly superseded by the agency's Good Guidance Practices, 21 C.F.R. $\int 10.115$ (declaring that guidances are nonbinding at $\int 10.115$ (i)(i), (i)(iv)), there remains some confusion. See, e.g., Lewis, supra note 246.

268. Mendelson argues that regulated parties comply with guidance documents rather than bear the expense, uncertainty, and acrimony of challenging them in court. Mendelson, supra note 144, at 407-08. This does not address guidance documents that are un- or underenforced by the agency, which parties would have little incentive to challenge as they age and become stale. Nevertheless, Seiguer and Smith found that "in practice, most of those interviewed [from the FDA and regulated industries] said that industry treats guidances no differently than rules." Seiguer \& Smith, supra note 203, at 29-30 (noting that this response reflected "the majority of those interviewed," and emphasizing that "industry is loathe to diverge from the agency's current thinking embodied in the guidance").

269. Mendelson, supra note 144, at 407-08; Seiguer \& Smith, supra note 203, at 29-30.

270. See Comm. on Gov'T Reform, Non-Binding Legal EfFect of Agency Guidance Documents, H.R. ReP. No. 106-1009, at 8-9 (2000); Mendelson, supra note 144 , at $400 \&$ n.17 (noting that the Committee's critiques "probably led the agencies to add disclaimers more systematically").

271. Of course, the FTC is careful to note that such enforcement would rely on statutory violations. 16 C.F.R. $\int 1.5$ (2013) ("Failure to comply with the guides may result in corrective action by the Commission under applicable statutory provisions. Guides may relate to a practice common to many industries or to specific practices of a particular industry."). 
As with rules, the APA requires agencies to publish most guidance documents in the Federal Register or in some other accessible source. ${ }^{272}$ Sometimes Congress even requires agencies by statute to publish guidances. ${ }^{273}$ As a result, many agencies, particularly the FDA, find themselves dedicating substantial time and resources to guidances. ${ }^{274}$

As Elizabeth Magill suggests, we might be more concerned with the outcome of agency action than "the package in which it is wrapped." 275 But Magill also notes that policymaking form dictates important things like its scope, the parties' procedural rights, enforceability, and judicial review. ${ }^{276}$

Moreover, the intuition that guidances give industry timely notice of new requirements while rulemaking does not is probably overwrought. Draft guidances are sometimes never finalized and agencies propose rules far before they are finalized. ${ }^{277}$ The regulatory uncertainty argument thus rings hollow as to form. In fact, both the FDA and industry representatives observed that the agency often takes a long time to articulate a concrete position on new issues, regardless of whether it chooses rulemaking or guidance. ${ }^{278}$ The FDA's draft guidances are known to linger for years before being finalized. ${ }^{279}$ Many morph into de facto final guidances, ${ }^{280}$ as the 1989 Draft Software Policy did.

Finally, differences in form may be overstated because they are not mutually exclusive. The reality is that "[m]any agencies regularly employ a mix of policymaking tools on a given issue-sometimes promulgating or amending a rule, sometimes bringing an enforcement action, and sometimes issuing a guidance document." ${ }^{281}$ Threats can start informally before

272. See 5 U.S.C. $\int 552(a)(1)(D)$ (2012) (requiring publication of interpretive rules and policy statements in the Federal Register); $\int 552(\mathrm{a})(2)(\mathrm{b})$ (requiring public accessibility of important guidance documents that are not in the Federal Register).

273. See, e.g., Raso, supra note 203, at 814 n.144 (citing the Small Business Regulatory Enforcement Fairness Act of 1996 \212, 5 U.S.C. \601 (2012), which requires agencies to issue compliance guides for small businesses on important rules).

274. See Seiguer \& Smith, supra note 203, at 24 (quoting an anonymous interviewee as stating, "Ideally, [guidances] should be faster and more flexible, but in practice, they may take as long as rules to develop.").

275. Magill, supra note 55, at 1419 (explaining why courts might be reluctant to review the vehicles agencies choose to use for policymaking, ultimately deciding that form does matter).

276. Id. at 1420 .

277. A recent commentary finds that, on balance, guidances benefit regulated industry, generalizing this point on regulatory certainty. See Lewis, supra note 246, at 541.

278. See Seiguer \& Smith, supra note 203, at 31.

279. See id.

280. See id.

281. Magill, supra note 55, at 1410. 
percolating into adjudication. For example, the FDA issues frequent "warning letters" to alleged regulatory violators. Warning letters are informal and are not considered official enforcement action. ${ }^{282}$ But the industry treats FDA warning letters as precedent, and lawyers advise clients based on them. The FDA's warning letters all cite specific statutory or regulatory violations, which then form the basis of any subsequent judicial enforcement.

In the end, the choice of policymaking form may not be as stark as it once was. And one form does not preclude another. But the FDA's decision to address software by guidance, to the exclusion of rulemaking, necessarily weakened its enforcement posture.

\section{DURABILITY}

The third question for agencies confronting disruptive innovation is how durable to make their policies. A concern with rulemaking is that it might be too durable for evolving technologies, hence the intuitive appeal of informal "threats." Agencies can temper concerns over the timing and form of policies by manipulating how long the policy will endure.

Of course, a policy's durability will be dictated in large part by its form. ${ }^{283}$ For example, we might be particularly concerned about the durability of guidances given the transience of agency leadership. Political appointees, who often set regulatory priorities, spend an average of only eighteen to twentyfour months with their agencies. ${ }^{284}$ Transient appointees, not to mention transient administrations, can undermine agency guidances by not adhering to them or by simply deprioritizing them. Although rules are also subject to amendment and rescission, they tend to be more resilient. ${ }^{285}$

The trick is to craft enduring policy under high uncertainty. ${ }^{286}$ Even large federal bureaucracies like the FDA cannot make perfectly calibrated decisions about new products or conduct. ${ }^{287}$ So-called "timing rules," contemplated by Gersen and Posner in the legislative context, ${ }^{288}$ might help.

282. The FDA includes "warning letters" in its definition of informal enforcement actions. 21 C.F.R. $\int 100.2(j)(1)$ (2013).

283. See Raso, supra note 203, at 803.

284. Id. at 803 (citing Paul C. Light, Our Tottering Confirmation Process, BROOKINGS (Spring 2002), http://www.brookings.edu/articles/2002/spring_governance_light.aspx).

285. Id.

286. See generally Fried, supra note 182, at 146-51 (discussing economic and empirical literature of decision making under uncertainty, weighing ex ante versus ex post decision making).

287. See Wu, supra note 11.

288. See generally Gersen \& Posner, supra note 146. 
Like legislators, regulators can manipulate the timing and duration of their interventions. ${ }^{289}$ Options include mandatory deadlines, waiting periods, interim periods, phases, and sunsets. ${ }^{290}$ These can control the timing of how laws are considered, enacted, and implemented, with the purpose of achieving some optimum result in the public interest. ${ }^{291}$ For example, agencies frequently use interim final rules to impose new requirements immediately while extending public comment on them. Such tools can be most useful when operating under uncertainty, as they allow lawmakers to "economize on legislative costs, address problems quickly or enable citizens to adjust, and handle uncertainty about the effects of a legislative proposal." 292 The more inchoate the technology, the less "durable" the regulator might want its policy to be. ${ }^{293}$

Here, two particularly promising possibilities are sunsets and deadlines. Other possibilities include deferred or conditional rulemaking, ${ }^{294}$ although these might only encourage further delay. ${ }^{295}$

\section{Sunsets}

Regulators can ease their anxiety over regulating new technologies prematurely or incorrectly by using sunsets-regulating temporarily. Congress frequently uses sunset clauses and other forms of temporary legislation that specify a finite duration. ${ }^{296}$ Sunsets are useful when the benefits of intervening are uncertain, as they reduce the costs of errors and allow regulators to gather better information. ${ }^{297}$ They can also counterbalance

289. See id. at 545 (defining a "timing rule" as "a rule that substantially affects the timing of government action, including legislation and executive action," and typically includes deadlines and mandatory delays).

290. Id.

291. Id. at 546.

292. Id. at 563.

293. See Gervais, supra note 11, at 701.

294. See Gersen \& Posner, supra note 146, at 562 (describing deferred and conditional legislation).

295. Gersen and Posner detail, somewhat optimistically, four benefits of delay rules for administrative agencies: (i) they allow agencies to gather more information, (ii) they "might reduce the effect of deliberative pathologies" like polarization over an issue, (iii) they might allow agency executives to better oversee major initiatives, and (iv) they could mitigate interest group incentives to weaken the rule. $I d$. at 588 . These benefits are suspect, as noted above.

296. See Jacob E. Gersen, Temporary Legislation, 74 U. CHI. L. REV. 247, 250 (2007) (refuting "the notion that temporary legislation is a new, peculiar, or particularly suspect legislative tool"); Gersen \& Posner, supra note 146, at 562 n.78 (noting that sunset clauses date back to the First Congress).

297. See Gersen, Temporary Legislation, supra note 296, at 248, 266-78 (noting that "when initial decisions are likely to be wrong, staged decision procedures facilitate the correction of 
cognitive biases in assessing uncertainty and overreacting to new risks. ${ }^{298}$ Sunset clauses proliferated among states during the regulatory reform movement of the 1970s and 1980s, on the theory that they would encourage more legislative oversight and thus make agencies more efficient and more responsive. ${ }^{299}$

Despite their deregulatory roots, sunset clauses might be useful for addressing disruptive innovation. Temporary regulation would allow agencies like the FDA to impose some standards as the technology gestates and the agency learns more about it. Sunset regulation would impose binding, enforceable requirements in the meantime. As such, it could serve as a stopgap, ${ }^{300}$ allowing us to capture the public benefits that we would otherwise forego by deferring regulation entirely.

Sunsets certainly are not a panacea. Like other variations on the regulatory process, they are susceptible to strategic behavior ${ }^{301}$ and, as emphasized above, the wait for more information is not always worthwhile. But sunsets decrease the costs of premature or incorrect regulation by timelimiting the damage they can inflict. Moreover, the argument that temporary regulation would generate too much uncertainty for industry is tempered by the reality that sunset laws can always be reauthorized or extended, and that "permanent" regulation can always be amended or repealed. ${ }^{302}$ Finally, wrapping the temporary policy in a regulation rather than a guidance would make it more durable. ${ }^{303}$ Had the FDA taken this approach with software, it could have provided a much-needed regulatory backbone-one that would be enforceable but also amenable to occasional updates as computing advanced.

errors, and this is particularly likely to be the case in policy contexts dominated by uncertainty").

298. See id. at 269-72 (noting that "new policy initiatives are often enacted in the immediate aftermath of realized or recognized risks" and that "staged decision procedures are utilized as compensation mechanisms for conditions of uncertainty in many other fields," citing examples).

299. Id. at 259-60.

300. See id. at $273-74$.

301. See id. at 275; Lawrence Lessig, Republic, Lost: How Money Corrupts CONGRESS-AND A PLAN TO STOP IT 203-06 (2011) (critiquing sunset legislation in the tax code).

302. Gersen, Temporary Legislation, supra note 296, at 261.

303. Gersen addresses durability in light of public choice theory and the political calculations it can generate. See id. at 279-86. 


\section{Deadlines}

To address the concern that an agency's initial restraint will calcify into a long-term laissez faire posture, Congress might set a regulatory deadline for the agency. Congress frequently does. ${ }^{304}$

The scant scholarship scrutinizing regulatory deadlines suggests that they have both advantages and limitations, particularly on the procedures agencies use, the extent of public participation, and the duration of the agency's action. ${ }^{305}$ Their most obvious advantage is to confront persistent agency delay. ${ }^{306}$ Deadlines can be desirable when "it is more important that a rule exist than it be right." 307 Congress has imposed deadlines on numerous agencies, particularly the EPA. ${ }^{308}$ The most familiar FDA examples are the various statutory deadlines for approving new drug approval applications ("NDAs"), ${ }^{309}$ which demonstrate the dynamics between the agency and the pharmaceutical industry. ${ }^{310}$

Congressional deadlines can counterbalance barriers to challenging agency delay or inaction. ${ }^{311}$ Jacob Gersen and Anne O'Connell found that although deadlines speed up agency action only modestly, the impact on HHS rulemaking is remarkable, reducing the average length by more than forty percent (from 817 days to 445 days). ${ }^{312}$ Procedurally, deadlines tend to correlate with interim final rules, which legally bind while the agency gathers public comments. ${ }^{313}$ Deadlines also correlate with more comment periods,

304. See Gersen \& Posner, supra note 146, at 545; Gersen \& O’Connell, supra note 204.

305. Gersen \& O’Connell, supra note 204, at 942-49.

306. Id. at 927.

307. Id. at 971 (noting that such cases can be rare).

308. Id. at 939, 981 tbl.2 (tallying 611 statutory deadlines for the EPA and 940 for the Department of Commerce).

309. Prescription Drug User Fee Act of 1992, Pub. L. No. 102-571, 106 Stat. 4491 (1992) (codified in scattered sections of 21 U.S.C.).

310. Daniel P. Carpenter, Groups, the Media, Agency Waiting Costs, and FD A Drug Approval, 46 AM. J. POL. SCI. 490 (2002). Of course, the power dynamic is complicated by the (now quite hefty) user fees required by the Prescription Drug User Fee Act (PDUFA) and its reauthorizations. See 21 U.S.C. \379h(c)(4) (2012); FDA, Prescription Drug User Fee Rates for Fiscal Year 2013, 77 Fed. Reg. 45,639, 45,642 (Aug. 1, 2012) (setting the fee for filing a New Drug Approval ("NDA") application at \$1,958,000 for fiscal year 2013).

311. See Gersen \& O'Connell, supra note 204, at 927-28, 951-54 (noting that deadlines sometimes "provide a rare opportunity for parties to successfully sue for agency inaction under section 706(1) of the APA").

312. Id. at 945-46, 988 tbl.12. Gersen and O'Connell gathered data between April 1988 to October 2003 from agency reports in the Unified Agenda of Federal Regulatory and Deregulatory Actions, published semiannually in the Federal Register. Id. at 938 n.57.

313. Id. at 943-44. 
probably because Congress tends to use deadlines for more significant actions. ${ }^{314}$

On the downside, deadlines can exacerbate the cognitive bias to overestimate newer, higher-profile risks over older, established ones. ${ }^{315}$ Yet, in the case of medical device software, the newer risks demonstrated by mobile technologies highlight longstanding risks with software that the FDA historically under-regulates. ${ }^{316}$

Another downside is that deadlines might prompt industry efforts to defeat or weaken the regulation preemptively. Again, this concern is not overwhelming, as agencies already publish Notices of Proposed Rulemaking ("NPRM") and even Advanced Notices of Proposed Rulemaking ("ANPRM") that forecast their interventions. ${ }^{317}$ Interim final rules also serve this purpose by binding the public (hence the "final"), but only for a limited time (hence the "interim"). ${ }^{318}$

In short, agencies can manipulate the durability of their policies. The FDA's 1989 software policy was not durable enough, and in fact, it did not endure.

\section{ENFORCEMENT}

Once an agency has settled on when and how to regulate a new technology, it must decide how rigorously to enforce its policy. Executive agencies have unmistakable discretion here. ${ }^{319}$ Indeed, agency discretion may reach its apex versus judicial interference in matters of enforcement. ${ }^{320}$ As a practical matter, agency discretion is limited only by political and resource constraints.

314. Id. at 943 .

315. Id. at 974 .

316. Cortez, supra note 78 (detailing some of the risks of mobile health technologies and how these echo some of the early concerns with primitive device software).

317. For a discussion of why agencies sometimes use ANPRM, see Barbara H. Brandon \& Robert D. Carlitz, Online Rulemaking and Other Tools for Strengthening Our Civil Infrastructure, 54 Admin. L. REV. 1421, 1465-68 (2002); Alan B. Morrison, OMB Interference with Agency Rulemaking: The Wrong Way to Write a Regulation, 99 HARV. L. REV. 1059, 1065 (1986) (criticizing the use of ANPRM as defensive and dilatory). For a discussion of the dynamics of NPRM, see Gersen \& Posner, supra note 146, at 587.

318. See Adoption of Recommendations, 60 Fed. Reg. 43,108, 43,110-12 (Aug. 18, 1995) (discussing interim final rulemaking by several agencies and endorsing its use in certain circumstances); Michael Asimow, Interim-Final Rules: Making Haste Slowly, 51 ADMIN. L. REV. 703 (1999); Gersen \& Posner, supra note 146, at 587.

319. See Heckler v. Chaney, 470 U.S. 821, 828-35 (1985); Lisa Schultz Bressman, Judicial Review of Agency Inaction: An Arbitrariness Approach, 79 N.Y.U. L. REV. 1657 (2004).

320. See Bressman, supra note 319, at 1705-10 (analyzing the Supreme Court's decision in Norton v. S. Utah Wilderness Alliance, 542 U.S. 55 (2004)). 
But enforcement discretion still demands fidelity to the agency's statutory responsibilities, and, above all, to the public interest. Agencies may be perfectly justified in tempering early enforcement against new technologies. Yet, as the innovation matures and as its risks become more evident, these initial justifications can become threadbare, as demonstrated by the FDA's history with software.

This argument counters several deeply rooted cultural norms about government regulation and technology. The overzealous regulator has long been an archetype in American political discourse. The idea that federal agencies systematically over-regulate is an old one, reaching a crescendo during the Reagan era, ${ }^{321}$ with a renewed vigor today. But, as Nicholas Bagley and Richard Revesz argue, this idea is generally wrong. ${ }^{322}$ Still, the intuition endures. In fact, efforts to reform federal regulation often do so primarily with regulated industry in mind, rather than regulatory beneficiaries. ${ }^{323}$ Some even argue that new technologies will generally regulate themselves. ${ }^{324}$

It is hard not to notice the cognitive dissonance here. There is widespread recognition that compliance with regulations is spotty, ${ }^{325}$ and that agencies generally lack the resources and personnel to enforce the law optimally. ${ }^{326}$ Scholars have examined regulatory underenforcement in a number of contexts. ${ }^{327}$ Recent studies show that even when agencies do make

321. See Nicholas Bagley \& Richard L. Revesz, Centralized Oversight of the Regulatory State, 106 Colum. L. REV. 1260, 1263-66 (2006); McGarity, supra note 155, at 1484-91, 1491-98 (describing the arguments of those advocating for less (or no) regulation).

322. See generally Bagley \& Revesz, supra note 321 (strongly refuting the claim of rampant overregulation and arguing that agencies routinely under-regulate).

323. See Mendelson, supra note 144, at 429-31 (suggesting that, for a number of reasons, informal rulemaking and reform tend to disenfranchise beneficiaries); McGarity, supra note 155 , at 1467, 1476-77, 1478-79 (giving examples of industry-oriented reform efforts).

324. See, e.g., Gervais, supra note 11, at 689-90 (citing LAWRENCE LESSIG: CODE AND OTHER LAWS OF CYBERSPACE (1999) and considering copyright problems on the Internet). Gervais's analysis, however, is inapposite to many health and safety problems that require regulation.

325. See Freeman, supra note 230, at 3, 14-17 (noting "that implementation is inconsistent, and that enforcement is at best sporadic are by now uncontroversial claims.'); Solomon, supra note 230, at 822.

326. See Rena Steinzor \& Sidney Shapiro, The People's Agents and THE Battle to Protect the American Public: Special Interests, Government, and Threats to HeAlth, SAFETy, AND THE EnVIRONMENT 54-71 (2010) (discussing the "hollow government" problem, in which agency funding stagnates while statutory responsibilities grow); Rena Steinzor, The Truth About Regulation in America, 5 HARV. L. \& POL'Y REV. 323, 327-28 (2011).

327. Frequent targets include the EPA, FDA, FEC, OSHA, and SEC. But federal underenforcement of immigration law probably draws the most attention. See, e.g., Adam Cox \& Cristina M. Rodríguez, The President and Immigration Law, 119 YALE L.J. 458, 534-45 
the effort to pursue violations, they frequently fail to enforce judgments and settlements. ${ }^{328}$ Underenforcement is often attributed to agencies being underfunded and understaffed. ${ }^{329}$ But agencies may be reluctant to ask for more resources, lest they signal their own inefficiency or create new pressures to produce results commensurate with new resources. ${ }^{330}$ Thus, we lament the overzealous regulator despite actual evidence that most are not zealous enough. ${ }^{331}$

This narrative fits the FDA well. The agency has been criticized for lax oversight over virtually every product category in its jurisdiction, including food, ${ }^{332}$ drugs, ${ }^{333}$ and medical devices. ${ }^{334}$ In response, former FDA officials

(2009); Stephen Lee, Private Immigration Screening in the Workplace, 61 STAN. L. REV. 1103, 1126-29 (2009). For works that address regulatory underenforcement more generally, see Steinzor, The Truth About Regulation in America, supra note 326; Matthew C. Stephenson, Public Regulation of Private Enforcement: The Case for Expanding the Role of Administrative Agencies, 91 VA. L. REV. 93, 116-17 (2005).

328. A remarkable recent study found that regulators systematically undercollect corporate fines and penalties. See Ezra Ross \& Martin Pritikin, The Collection Gap: Underenforcement of Corporate and White-Collar Fines and Penalties, 29 YALE L. \& POL'Y REV. 453, 456, 473-74 (2011) (finding that regulatory agencies "never collect the vast brunt of regulatory and criminal penalties," pointing to the Justice Department's collection rate of only $4 \%$ of its criminal penalties and fines). In 2006, the Justice Department collected \$35 billion in penalties and fines. Martha Mendoza \& Christopher Sullivan, More Corporations Stiffing Government on Fines, USA TODAY, Mar. 19, 2006, http://usatoday30.usatoday.com/ news/washington/2006-03-19-unpaid-fines_x.htm. Federal regulators leave a lot of money on the table, due to a combination of insufficient resources, insufficient incentives, institutional malaise, agency capture, and, perhaps, simply confusion. See Ross \& Pritikin, supra, at 496-507.

329. See, e.g., Freeman, supra note 230, at 17 (describing how the EPA's insufficient funding and personnel trace back to Congress).

330. See Ross \& Pritikin, supra note 328, at 502-03. Ross and Pritikin note perceptively that for agencies, it may be "[b]etter to do poorly with little than risk doing poorly with a lot," and that agency leaders may be reluctant "to admit existing deficiencies." Id. at 502-03. Conversely, they "may risk funding if they establish that they are doing too well" at collecting fines. Id. at 503 n. 325 .

331. This dynamic has been highlighted in other areas, notably for street and violent crimes. See Alexandra Natapoff, Underenforcement, 75 FORDHAM L. REV. 1715 (2006).

332. See, e.g., Inst. Of Med., Enhancing Food SAFety: The Role of The Food AND DRUG ADMINISTRATION (2010) (criticizing the agency's piecemeal authority and oversight over food safety); Diana R.H. Winters, Not Sick Yet: Food-Safety-Impact Litigation and Barriers to Justiciability, 77 BROOKLYN L. REV. 905, 913-15 (2012).

333. See, e.g., Inst. of Med., The Future of Drug Safety: Promoting And Protecting the Health of the Public (2007) (finding major, sometimes structural deficiencies with the FDA's approach for regulating the safety of prescription and over-thecounter drugs).

334. See, e.g., Inst. Of Med., Medical Devices and the Public’s Health: The FDA 510(K) Clearance Process AT 35 YeArs (2011) (finding major flaws with the primary process by which most medical devices are introduced to the U.S. market). 
argue that the agency suffers from "the hollow government syndrome," whereby it is simultaneously saddled not only with expanding jurisdiction, but also with "stagnant resources and the consequent inability to implement or enforce its statutory mandates." 335 It can be easy to criticize an overwhelmed agency.

At the same time, these excuses dissolve the longer a problem lingers. Underenforcement can negate the value of even optimally timed regulation. ${ }^{336}$ It can also erode careful decisions about the proper form and durability of interventions. The decision to proceed by guidance or even by more collaborative forms of soft regulation is easier to justify if the agency provides a traditional hard law backstop via binding rules or enforcement. As new governance proponents like Ian Ayres and John Braithwaite observe, "[r] egulatory agencies will be able to speak more softly when they are perceived as carrying big sticks." 337 Thus, while the FDA's decision to address software by guidance may have been defensible in 1987 or even 1989, it became less so over time, as software products proliferated and enforcement continued to lag.

How do these lessons apply to disruptive innovation? Again, this Article tempers the suggestion that agencies should rely on "threats" as new technologies mature. The primary example Wu uses is the FCC's early Internet policy, which warned Internet service providers to maintain net neutrality. ${ }^{338}$ Chairman Powell's speech warned the broadband industry to preserve net neutrality. ${ }^{339}$ But the FCC did not make an empty threat. Just one year later, the FCC investigated a telephone company for violating one of these principles, ${ }^{340}$ citing violations of the Communications Act of $1934 .^{341}$ Shortly after the settlement, the FCC published a policy statement explaining

335. Peter Barton Hutt, Recent Developments: The State of Science at the Food and Drug Administration, 60 Admin. L. REV. 431, 432 (2008).

336. See Super, supra note 68, at 1404.

337. IAn Ayres \& John Braithwaite, Responsive Regulation: Transcending THE Deregulation DeBate 6 (1992); see also Freeman, supra note 230, at 14-17 (critiquing the EPA's process of enforcing standards through permits).

338. See Wu, supra note 11. "Net neutrality," of course, is a phrase Wu coined. Tim Wu, Network Neutrality, Broadband Discrimination, 2 J. TeleCOM. \& HigH TECH. L. 141 (2003).

339. Wu, supra note 11, at 1844-45 (citing Michael K. Powell, Chairman, FCC, Preserving Internet Freedom: Guiding Principles for Industry, Remarks at the Silicon Flatirons Symposium on "The Digital Broadbrand Migration: Toward a Regulatory Regime for the Internet Age" (Feb. 8, 2004), available at http://hraunfoss.fcc.gov/edocs_public/ attachmatch/DOC-243556A1.pdf).

340. See Wu, supra note 11, at 1845; Madison River Commc'ns, LLC, 20 FCC Rcd. 4295 (2005), available at http://digital.library.unt.edu/ark:/67531/metadc4102/m1/371.

341. Madison River, 20 FCC Rcd. 4295, 4296 (citing the Communications Act of 1934, 47 U.S.C. S 201(b)); Weiser, supra note 39, at 563. 
four Internet freedoms, ${ }^{342}$ which preceded a legally binding rule just six years later. ${ }^{343}$ The FCC buttressed the rule by enforcing it. ${ }^{344}$

Adjudication and enforcement require sustained effort. ${ }^{345}$ The FDA has brought intermittent enforcement actions against software products, particularly via warning letters, ${ }^{346}$ but it has not pursued enough high-profile cases to offset its primary reliance on nonbinding (and since withdrawn) guidance.

Underenforcement can undermine an agency's credibility, and failure to enforce can compound other problems for agencies. ${ }^{347}$ A caution voiced during a recent FDA public workshop on software products was that if too many people do not follow the FDA's rules, they would undermine the entire system. ${ }^{348}$ As noted in Part III, this is close to what happened with medical device software. And history risks repeating itself with the newest generation of software products for mobile platforms. ${ }^{349}$

Of course, it is hard to discuss FDA enforcement without appreciating its gatekeeping authority over new technologies. Agencies, like the FDA, that enjoy preapproval power can leverage it to better enforce their policies whether those policies are technically binding or not. ${ }^{350}$ In the case of software products, the FDA's statutory authority to pre-approve and preclear devices gives it gatekeeping authority. ${ }^{351}$ FDA guidances thus demand respect. Yet this leverage dissolves when the FDA exempts certain products from premarket review, as it has with many lower risk categories of devices,

342. Appropriate Framework for Broadband Access to the Internet over Wireline Facilities, Policy Statement, 20 FCC Rcd. 14,986 (Aug. 5, 2005), available at http://digital. library.unt.edu/ark:/67531/metadc4091/m1/708.

343. See Wu, supra note 11, at 1852; Preserving the Open Internet, 25 FCC Rcd. 17,905 (Dec. 21, 2010), available at http://digital.library.unt.edu/ark:/67531/metadc39308/m1/451.

344. See Weiser, supra note 39, at 584-89.

345. See id. at 585-86.

346. See, e.g., supra note 140.

347. See Weiser, supra note 39, at 586 (discussing the FCC's underenforcement).

348. FD A Public Workshop, supra note 80 (Statement of Grant Elliott, Voxiva).

349. Cortez, supra note 78 (drawing parallels between the FDA's initial approach to device software and its approach to the latest generation, embodied in mobile medical applications for smartphones, tablets, and other wireless devices).

350. See Raso, supra note 203, at 803 (noting that the FDA and FCC both enjoy gatekeeping authority that encourages regulated industries to comply with the agencies' guidances). See generally CARPENTER, supra note 19. For criticisms of FDA's gatekeeping authority over drugs, see C. Frederick Beckner, III, The FDA's War on Drugs, 82 GEO. L.J. 529 (1993); Michael P. VanHuysen, Note, Reform of the New Drug Approval Process, 49 ADMIN. L. REV. 477 (1997).

351. Federal Food, Drug, and Cosmetic Act $\int 510(\mathrm{k}), 21$ U.S.C. $\iint 360 \mathrm{e}(2012)$. 
like the medical device data systems mentioned above. ${ }^{352}$ Gatekeeping leverage is less useful when the product has already passed through the gate, or when the gates are left wide open. ${ }^{353}$

So, what is the best way to address suboptimal enforcement by resourcestrapped agencies like the FDA? Some commentators suggest relying on citizen enforcement and private rights of action. ${ }^{354}$ Nina Mendelson argues that expanding such mechanisms could not only increase overall enforcement, but also redress some of the procedural deficiencies of agencies relying on guidance documents. ${ }^{355}$ In effect, we could deputize citizens and interest groups to use private resources to enforce regulatory obligations that might otherwise go un- or under-enforced. ${ }^{356}$

Currently, citizen suits are somewhat rare in administrative enforcement schemes, outside of environmental statutes. ${ }^{357}$ Private rights of action are also rare. ${ }^{358}$ However, Mendelson argues that “[r] egulatory beneficiaries' concerns over inadequate agency enforcement of statutory provisions could be addressed by expanding citizen enforcement provisions to encompass obligations under a broader array of health, safety, and environmental laws." ${ }^{359}$ These vehicles would remind agencies that they have constituents other than industry. They could also combat agency "slack." 360 Of course, it might be difficult for regulatory beneficiaries to "detect and document" regulatory violations. ${ }^{361}$ And there are other problems, ${ }^{362}$ including the reality

352. Medical Device Data Systems, 76 Fed. Reg. 8637 (Feb. 15, 2011) (codified at 21 C.F.R. \880.6310 (2011)).

353. See Seiguer \& Smith, supra note 203, at 28 (noting that when FDA wants enforceability, it chooses rulemaking over guidances, particularly when regulation slants towards postmarket rather than premarket requirements).

354. See, e.g., Stephenson, supra note 327.

355. See Mendelson, supra note 144, at 450-52.

356. See Stephenson, supra note 327, at 107-08.

357. See Barton H. Thompson, Jr., The Continuing Innovation of Citizen Enforcement, $2000 \mathrm{U}$. ILL. L. REV. 185, 191-92 (2000) (discussing private enforcement of environmental laws); Mendelson, supra note 144, at 450-51 (citing examples of citizen suits).

358. See Mendelson, supra note 144, at 451 (noting that the major exceptions occur in securities and civil rights statutes).

359. Id.

360. Agency "slack" is "the tendency of government regulators to underenforce certain statutory requirements because of political pressure, lobbying by regulated entities, or the laziness or self-interest of the regulators themselves." Stephenson, supra note 327, at 110 (internal citations omitted).

361. See Mendelson, supra note 144 , at 451.

362. See id. at 452 (noting that citizen suits are expensive, may face constitutional difficulties, and can interfere with agencies' ability to set their enforcement priorities and allocate scarce regulatory resources); Stephenson, supra note 327, at 114-20 (listing problems with private enforcement). 
that private enforcement would probably need to be authorized by Congress. ${ }^{363}$ But for consumer products and markets, consumers might serve as early sentinels of problems. ${ }^{364}$

In short, agencies need not be so deliberate and tentative with regulating innovations - even disruptive ones. If agencies are concerned with regulating prematurely or incorrectly, then they can experiment with timing rules, push Congress to authorize private enforcement, or try other adaptations of traditional interventions that reduce the costs of errors. If agencies do choose to proceed by making threats, then they should use them as a short-term precursor to more decisive action, as the FCC did, and guard against relying on them as a long-term crutch, as the FDA did.

\section{CONCLUSION}

Periodically, regulators are confronted by novel products, technologies, or business practices that fall within their jurisdiction but do not fit comfortably within their regulatory frameworks. Agencies face "regulatory disruption." Many scholars and policymakers intuit that the appropriate response is for regulators to be cautious, not decisive. As Tim Wu recently argued, agencies should make "threats" to encourage desired behavior or discourage undesired behavior.

Though intuitive, the idea of using "threats" as a tentative, flexible initial posture can easily calcify, creating a weak default position that leads to suboptimal regulation over longer periods. Regulatory inertia can be hard to break without an external shock, usually a tragedy or massive failure that reignites interest in regulation.

This discussion implicates not just the FDA's or the FCC's consideration of new technologies, but other agencies' as well. If agencies are concerned about regulating novel products or practices prematurely or erroneously, they can experiment with timing and enforcement methods to reduce the risks of both. Agencies can use experimental rules, regulatory sunsets, or rulemaking deadlines to calibrate their approach to novel technologies or business practices. Also, citizen suits or private rights of action might help correct systematic underenforcement by resource-strapped regulators, who might find themselves even more strapped for resources when new products, firms, or even industries materialize within their jurisdictions.

363. See generally Stephenson, supra note 327 (arguing that Congress should grant such delegations, and if not, courts should infer it).

364. See id. at 108 (noting that private parties directly affected by regulatory violators' conduct may be better suited to detection violations). 
The plight of the modern regulator is to adapt old regulatory frameworks to new technologies and practices. This should not be as paralyzing as it seems. 